\title{
Implementation of Bismuth Chalcogenides as an Efficient Anode: A Journey from Conventional Liquid Electrolyte to an All-Solid-State Li-Ion Battery
}

\author{
Rini Singh ${ }^{1}\left(\mathbb{D}\right.$, Pooja Kumari ${ }^{2}$, Manoj Kumar ${ }^{2}$, Takayuki Ichikawa ${ }^{1,3}$ and Ankur Jain ${ }^{3, *(D)}$ \\ 1 Graduate School of Engineering, Hiroshima University, 1-4-1 Kagamiyama, \\ Higashi-Hiroshima 739-8527, Japan; rini@hiroshima-u.ac.jp (R.S.); tichi@hiroshima-u.ac.jp (T.I.) \\ 2 Department of Physics, Malaviya National Institute of Technology Jaipur, Rajasthan 302017, India; \\ malikpooja720@gmail.com (P.K.); mkumar.phy@mnit.ac.in (M.K.) \\ 3 Natural Science Centre for Basic Research and Development, Hiroshima University, \\ Higashi-Hiroshima 739-8530, Japan \\ * Correspondence: ankur@hiroshima-u.ac.jp
}

Academic Editor: Guanglin Xia

Received: 4 August 2020; Accepted: 14 August 2020; Published: 15 August 2020

\begin{abstract}
Bismuth chalcogenide $\left(\mathrm{Bi}_{2} \mathrm{X}_{3} ; \mathrm{X}=\right.$ sulfur (S), selenium (Se), and tellurium (Te)) materials are considered as promising materials for diverse applications due to their unique properties. Their narrow bandgap, good thermal conductivity, and environmental friendliness make them suitable candidates for thermoelectric applications, photodetector, sensors along with a wide array of energy storage applications. More specifically, their unique layered structure allows them to intercalate $\mathrm{Li}^{+}$ions and further provide conducting channels for transport. This property makes these suitable anodes for Li-ion batteries. However, low conductivity and high-volume expansion cause the poor electrochemical cyclability, thus creating a bottleneck to the implementation of these for practical use. Tremendous endeavors have been devoted towards the enhancement of cyclability of these materials, including nanostructuring and the incorporation of a carbon framework matrix to immobilize the nanostructures to prevent agglomeration. Apart from all these techniques to improve the anode properties of $\mathrm{Bi}_{2} \mathrm{X}_{3}$ materials, a step towards all-solid-state lithium-ion batteries using $\mathrm{Bi}_{2} \mathrm{X}_{3}$-based anodes has also been proven as a key approach for next-generation batteries. This review article highlights the main issues and recent advances associated with $\mathrm{Bi}_{2} \mathrm{X}_{3}$ anodes using both solid and liquid electrolytes.
\end{abstract}

Keywords: Bismuth chalcogenides; all-solid-state lithium-ion batteries; electrochemical properties

\section{Introduction}

The continuous depletion of fossil fuels and their hazardous byproducts are leading us in the search for clean and sustainable sources of energy [1,2]. During the past few decades, researchers have put huge efforts into the search for renewable sources of energy like solar energy, wind energy, tidal energy, etc. However, their time- and location-dependent availability again forced us to think in the search for energy storage technologies, which can balance the demand and supply efficiently. In addition to this, the reduction in $\mathrm{CO}_{2}$ emission is one of the biggest hurdles to overcome the global warming issue. Electrochemical batteries [3,4], fuel cells [5-7], solar cells [8,9], etc. are helping to reduce the carbon emission [10-12]. The most suitable and advantageous solution to fulfill these requirements is electrochemical batteries. Batteries are the most attractive way to store energy in a chemical form and convert it to electrical energy [13-16], when needed. The assembly for the battery consists of negative and positive electrodes, whereas electrolytes are used as a separator in the electrochemical batteries. 
A wide range of classification of batteries is available, including lithium-ion batteries, nickel-cadmium batteries, lead-acid batteries, nickel-metal hybrid batteries, etc. From this available class of batteries, Li-ion batteries are widely used due to their high specific energy density and high cyclic stability in comparison to rest. The schematic diagram of the Li-ion battery is depicted in Figure 1. A Japanese company, Sony, in 1992, launched the first commercial LIBs and it was a huge success, as in the year 1993, it sold 3 million units. Later, in 2001, Tesla commercialized these batteries in the use for electrical vehicle applications. Since then, many communication companies used these batteries in their mobiles, laptops, tablets, etc. These batteries provide many advantageous features on the commercial level i.e., high specific energy, long cycle life, low self-discharge, and their environmental friendliness $[10,17]$.

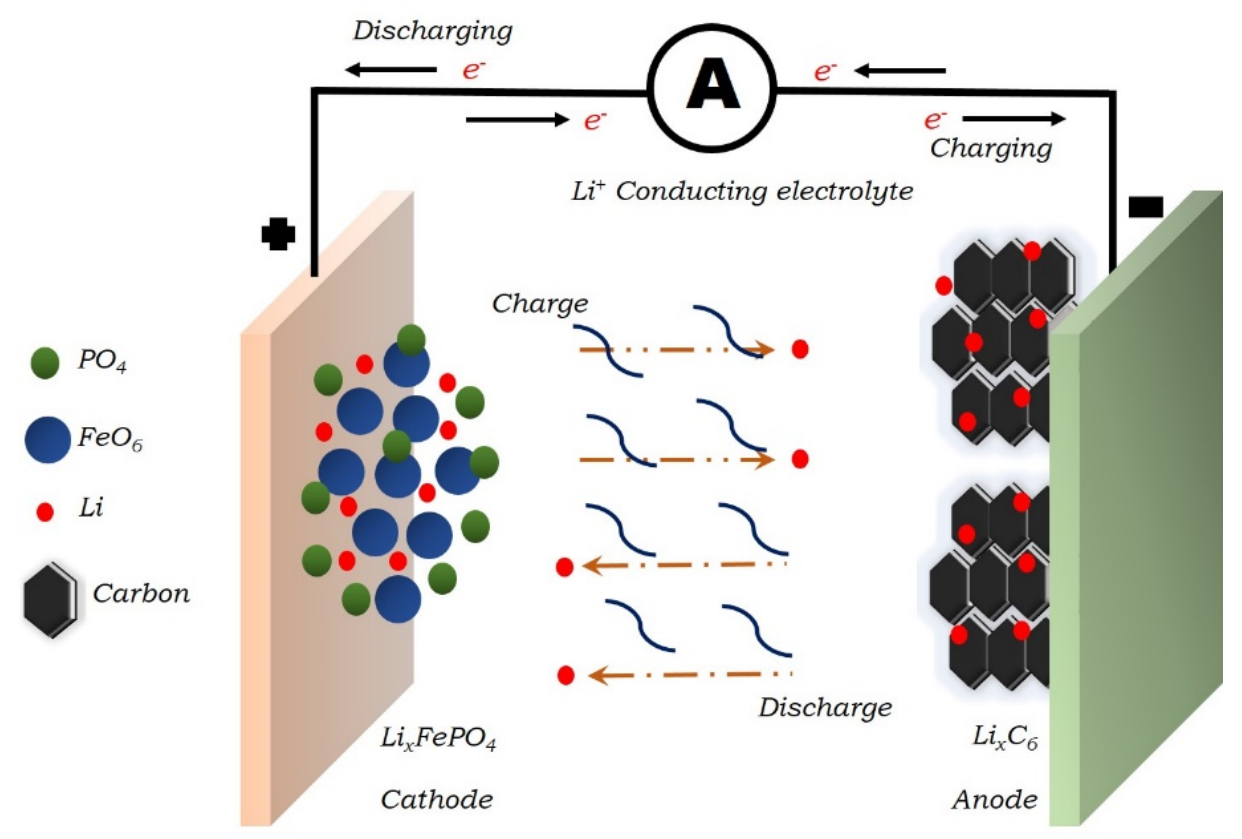

Figure 1. Schematic diagram of Li-ion batteries.

Continuous advancement in battery technology and smartphones has provided a more user experience. Moreover, these developments continue to demand more cycle life in electronic devices with thinner and lighter Li-ion batteries of higher energy densities. The commercial batteries are developed using liquid electrolytes and graphite-based anodes. However, the graphite has a very low theoretical capacity, i.e., $376 \mathrm{mAhg}^{-1}$. This lower specific capacity led us, researchers, to think of alternative anodes with a higher capacity and long cycle life.

Apart from the issues related to anode materials, the flammable liquid electrolytes associated with the conventional batteries also possess safety issues. These safety issues limit the mass application of this energy storage technique to electrical vehicles. The unsurpassed solution to overcome this problem is the replacement of these liquid electrolytes with solid electrolytes. Additionally, these solid-state electrolytes possess a higher energy density and higher power density. As we are all aware of the fact that organic liquids are more prone to fire, the use of solid electrolytes is a key point for battery technology to improve its safety standards due to the non-use of flammable organic liquid electrolytes [18-21]. Solid-state electrolytes can provide the advantages of a superior thermal stability, lower flammability, improved durability, and battery design simplicity, over conventional organic liquid electrolytes, even though the room-temperature ionic conductivity in solid electrolytes is still lower than that in liquid electrolytes [22-28].

The development of alternative anode materials for Li-ion batteries is continuously in progress to satisfy the industrial requirements. Bi and their chalcogenides are promising anodes for Li-ion batteries owing to their high volumetric energy density [29-31]. Bismuth (Bi) and its binary chalcogenides $\left(\mathrm{Bi}_{2} \mathrm{X}_{3}\right.$, 
$X=\mathrm{Te}, \mathrm{Se}$, and S) are known for their various applications like thermoelectric [32-34], sensors [35], photodetectors [36-38], photoelectrochemical sensors [39,40], etc. due to their unique properties, i.e., their unique layered structure, narrow bandgap, and their environmentally friendly nature [35]. $\mathrm{Bi}_{2} \mathrm{Se}_{3}$ and $\mathrm{Bi}_{2} \mathrm{Te}_{3}$ possess a rhombohedral $(\mathrm{R} 3 \mathrm{~m})$ structure, whereas $\mathrm{Bi}_{2} \mathrm{~S}_{3}$ consists of an orthorhombic crystal structure. Two Bi layers are sandwiched between $X(X=S, S e, T e)$ layers. These arrangements of $\mathrm{Bi}$ and $\mathrm{X}$ are called quintuple layers. These layers are connected together by weak Van der Waal forces [41,42]. This gap between the layers provides sufficient space for Li-ion intercalation and further provides channels for the transportation of ions [42]. This feature provides a better efficacy of these materials as an anode for LIBs [35]. The main stumbling block of these materials is their poor cyclability. To solve this issue, researchers have developed many methods to improve their cyclic performance. Nanostructuring is one of the popular methods, which can enhance the electrochemical performance by shortening the Li diffusion path and enhancing the surface area [43-45]. Sometimes, the agglomeration of nanoparticles results in the disconnection of active materials from the current collector. To overcome this issue, different forms of carbon matrix were prepared to immobilize the $\mathrm{Bi}_{2} \mathrm{X}_{3}$ nanostructures for the prevention of agglomeration [46-51]. In this review, we will discuss the different approaches towards the advancement of electrochemical performances of $\mathrm{Bi}_{2} \mathrm{X}_{3}$ materials.

\section{Development of Bi-Based Anodes for Li-Ion Batteries}

Before understanding the behavior of $\mathrm{Bi}_{2} \mathrm{X}_{3}$ materials, it is imperative to understand the reaction mechanism of $\mathrm{Bi}$ towards Li storage. Bismuth has higher theoretical gravimetric and volumetric capacities than carbon-based anodes. Along with the capacity, bismuth has one more advantage of its relatively high potential for Li-Bi alloy formation $(0.8 \mathrm{~V})$. This potential prevents the other materials in the anode from participating electrochemically in the reaction. However, its volume expansion is quite high during the alloying reaction, which directly affects the cyclic performance of the battery. In 2001, Crosnier et al. investigated bismuth as an anode material for Li-ion batteries and proposed the following reaction (1):

$$
\mathrm{Bi}+\mathrm{Li} \leftrightarrow \mathrm{Li}_{3} \mathrm{Bi}
$$

The above-mentioned reaction is reversible. This was the first initiative towards investigating bismuth as an anode material for Li-ion batteries; however, the results of the electrochemical performance were not promising [46-48]. Later, in 2002, Xiamming et al. investigated how to reduce volume expansion and the detailed reaction mechanism of Li-Bi reaction [52]. By reducing the thickness of the bismuth anode, they found a better performance in the battery. The thickness of the $\mathrm{Bi}$ anode sheet was kept in the micrometers order. The phase diagram of $\mathrm{Li}-\mathrm{Bi}$ suggests that $\mathrm{LiBi}$ and $\mathrm{Li}_{3} \mathrm{Bi}$ can be formed at normal conditions. From cyclic voltammetry $(\mathrm{CV})$ and $\mathrm{X}$-ray diffraction (XRD) studies, two potentials, i.e., 0.830 and $0.805 \mathrm{~V}$, corresponded to the $\mathrm{LiBi}$ and $\mathrm{Li}_{3} \mathrm{Bi}$ formation. The authors also suggested that the formation of $\mathrm{Li}_{3} \mathrm{Bi}$ instead of $\mathrm{LiBi}$ is mainly responsible for the mechanical degradation of the $\mathrm{Li}$-Bi electrode. The formation of $\mathrm{Li}_{3} \mathrm{Bi}$ alone resulted in a volume expansion of up to $177 \%$ when Li was inserted into Bi. The lithium insertion coefficient in LiBi alloy was found to be in the order of $10^{-3} \mathrm{~cm}^{2} / \mathrm{s}$. This low value suggested the intrinsic properties of the thin-layer electrode. These intrinsic properties include the orientation, crystallographic imperfection, fewer grain boundaries, and porosity of thin-layer electrodes. So, these results were quite interesting to understand the mechanism of alloying in the Li-Bi system. Till now, the reaction mechanism is crystal clear; however, enhancement of the electrochemical performance is still a challenge.

Since the use of nanomaterials in LIBs can improve cyclic stability by shortening the Li-ions' path, the addition of carbon-based materials with bismuth helps to improve the conductivity of the anode materials. Thus, to improve the performance of the bismuth-based anodes, Park and co-workers investigated the bismuth nanomaterials and their composite anodes [53]. They designed two different samples, i.e., $\mathrm{Bi} / \mathrm{C}$ (bismuth/carbon) composite and $\mathrm{Bi} / \mathrm{Al}_{2} \mathrm{O}_{3} / \mathrm{C}$ composites. In these samples, $\mathrm{Bi}$ nanocrystals were uniformly distributed over the amorphous carbon and mixture of $\mathrm{Al}_{2} \mathrm{O}_{3}$-carbon. Compared to these samples, pure $\mathrm{Bi}$ and milled Bi showed a poor performance in terms of cyclability. 
However, the specific capacity of $\mathrm{Bi} / \mathrm{C}$ composites after each cycle was found to gradually decrease. The possible reason for this was suggested as the mechanical cracking caused by the large volume change. In the reaction of $\mathrm{Li}-\mathrm{Bi}$, the formation of $\mathrm{Li}_{3} \mathrm{Bi}$ causes the major volumetric change as mentioned earlier. $\mathrm{Bi} / \mathrm{Al}_{2} \mathrm{O}_{3} / \mathrm{C}$ electrodes show relatively stable cyclic behavior. The high reversible capacity of $310 \mathrm{mAhg}^{-1}$ and a remarkable retention of $74 \%$ was achieved over 100 cycles. The better performance of this composite resulted from the uniform distribution of nanosized Bi crystallites. The strain generated during cycling could be accommodated by the amorphous and inactive $\mathrm{Al}_{2} \mathrm{O}_{3}$ whereas the buffering effect of the amorphous carbon matrix also played a significant role. During charging and discharging, the crystal structure change was observed as follows:

Discharging: $\mathrm{Bi}$ (Rhombohedral) $\rightarrow \mathrm{LiBi}$ (Tetragonal) $\rightarrow \mathrm{Li}_{3} \mathrm{Bi}$ (Cubic).

Charging: $\mathrm{Li}_{3} \mathrm{Bi}$ (Cubic) $\rightarrow \mathrm{LiBi}$ (Tetragonal) $\rightarrow \mathrm{Bi}$ (Rhombohedral).

Similarly, Yang and co-workers investigated Bi and Bi encapsulated with carbon (Bi@C) materials for lithium-ion batteries [54]. The reaction mechanism of Bi@C microspheres was understood by the cyclic voltammetry as shown in Figure 2a. No reduction peak was observed in the first cycle of Bi@C samples in the cathodic scan up to $0.01 \mathrm{~V}$; however, 2 peaks at 0.75 and $0.63 \mathrm{~V}$ originated in the 2 nd and 3rd cycles, which were assigned to the $\mathrm{LiBi}$ and $\mathrm{Li}_{3} \mathrm{Bi}$ formation, respectively. During the reverse scan, the $\mathrm{CV}$ curves showed only one peak instead of two expected peaks, which were suggested due to the overlapping of peaks. The charging/discharging curve (Figure 2b) suggested the first discharge capacity of $810.4 \mathrm{mAhg}^{-1}$, whereas the charging capacity was observed as $276.7 \mathrm{mAhg}^{-1}$. As such, the first coulombic efficiency was found to be only 37\%, as depicted in Figure 2c. This low coulombic efficiency was suggested due to solid interface electrolyte (SEI) layer formation, which is quite normal and crucial in the case of liquid electrolytes. The cyclic performance up to 100 cycles was found to be better, i.e., $280 \mathrm{mAhg}^{-1}$ at a current density of $100 \mathrm{mAg}^{-1}$ in the voltage range $0.01-2 \mathrm{~V}$ as shown in Figure 2c. Several reports stated that the cyclic stability of Bi-based electrodes remained less than $300 \mathrm{mAhg}^{-1}$ after 100 cycles [55-58].
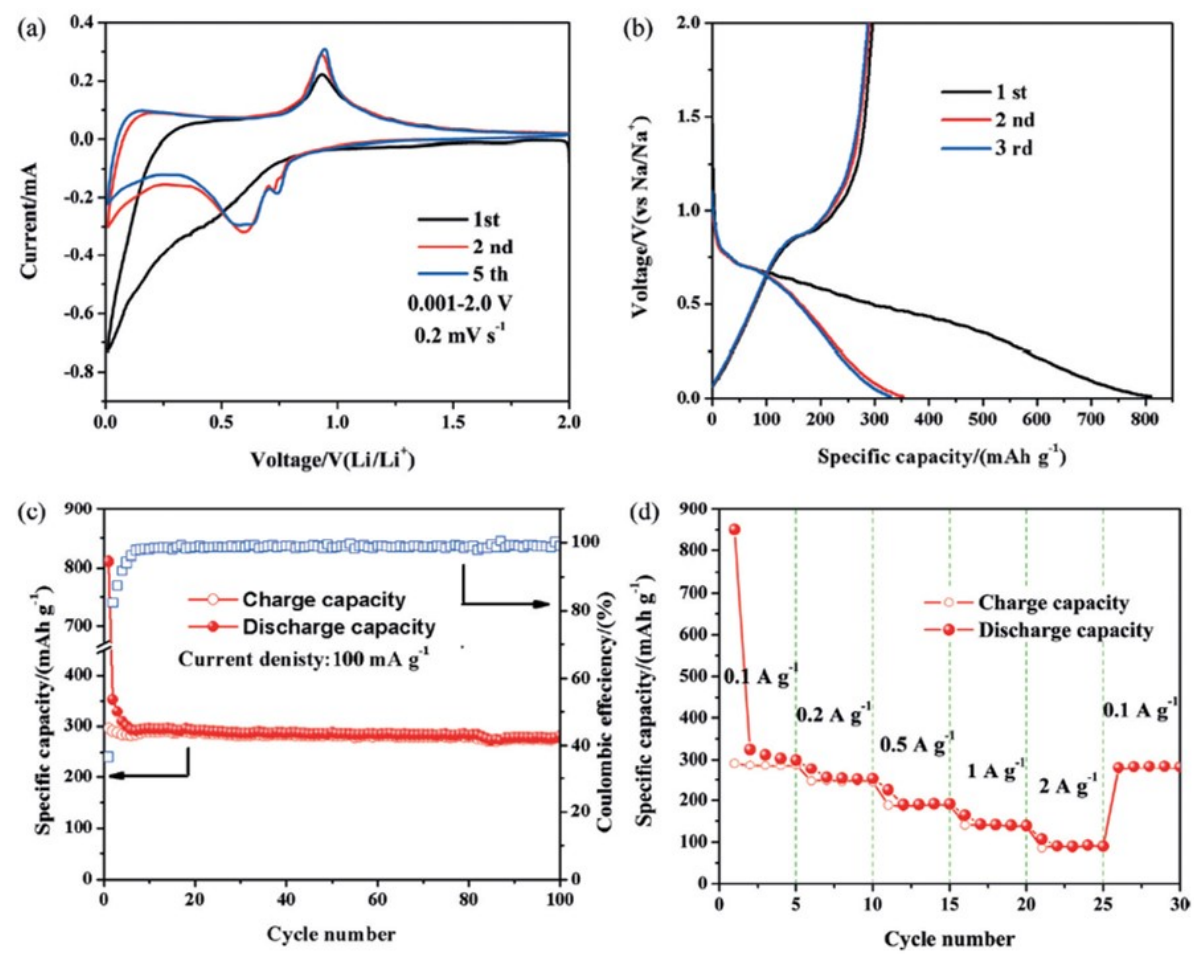

Figure 2. (a) Cyclic voltammograms (CV) (b) electrochemical charging and discharging (c) cyclic stability at $100 \mathrm{mAg}^{-1}$ rates. (d) cyclic stability at different current rates of Bi@C microspheres [54]. Reproduced with permission. Copyright 2016, Wiley. 
These lower capacity and cyclic stability issues were solved by the implementation of Bi anode in all-solid-state Li-ion batteries [59]. Jain and co-workers did excellent work in this regard. Details of all-solid-state Li-ion batteries (ASSLIBs) are already discussed in the introduction section. They proposed the bulk bismuth as a negative electrode for ASSLIBs. In the electrode preparation, lithium borohydride $\left(\mathrm{LiBH}_{4}\right)$ and acetylene black $(\mathrm{AB})$ were milled with bulk bismuth powder. The acetylene black provided the electrical conductivity to the anode whereas $\mathrm{LiBH}_{4}$ provided the path to $\mathrm{Li}$ ions. The electrochemical performance of the Bi-based electrode was tested between 0.1 and $1.5 \mathrm{~V}$ at the current rate of $0.1 \mathrm{C}$. The discharge capacity decreased from 478.7 to $394 \mathrm{mAhg}^{-1}$ after 100 cycles with stable coulombic efficiency as shown in Figure 3. This battery cell showed good performance as compared to the reports of Bi-based anodes with liquid electrolytes $[54,55]$. In this study, no cracks were observed even after 100 cycles. This implied that $\mathrm{LiBH}_{4}$ and $\mathrm{AB}$ worked as a binder, which provided the cushioning effect and accommodated the volume expansion efficiently without breaking the electrode, which resulted in an improvement of the cyclic stability.
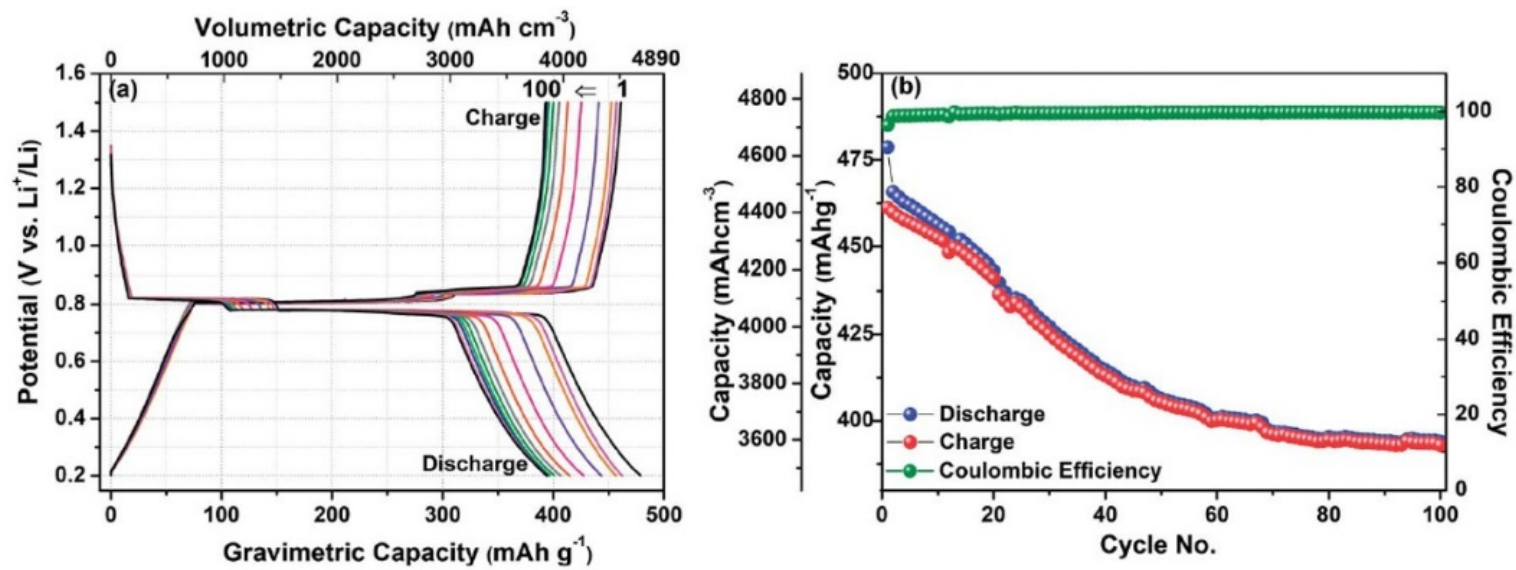

Figure 3. (a) Electrochemical charge-discharge of bulk Bi. (b) cyclic stability of bulk Bi [59]. Reproduced with permission. Copyright 2018, Royal Society of Chemistry.

\section{Reaction Mechanism of Bismuth Based Chalcogenides $\mathrm{Bi}_{2} \mathrm{X}_{3}(\mathrm{X}=\mathrm{S}, \mathrm{Se}$, and $\mathrm{Te})$}

Bismuth chalcogenides have been considered as a promising candidate as anode material for Li-ion batteries due to their unique layered crystal structure. The schematic diagram for layered structure of $\mathrm{Bi}_{2} \mathrm{X}_{3}$ is shown in Figure $4 \mathrm{a}$. During the reaction between $\mathrm{Bi}_{2} \mathrm{X}_{3}$ and Li, a total of 12 lithium react with the $\mathrm{Bi}_{2} \mathrm{X}_{3}$ materials in two steps and the formation of $\mathrm{Li}_{2} \mathrm{X}$ and $\mathrm{Li}_{3} \mathrm{Bi}$ takes place according to the following reactions:

$$
\begin{aligned}
& \text { Conversion reaction: } \mathrm{Bi}_{2} \mathrm{X}_{3}+6 \mathrm{Li}^{+}+6 \mathrm{e}^{-} \leftrightarrow 3 \mathrm{Li}_{2} \mathrm{X}+2 \mathrm{Bi}, \\
& \text { Alloying reaction: } 2 \mathrm{Bi}+6 \mathrm{Li}^{+}+6 \mathrm{e}^{-} \leftrightarrow 2 \mathrm{Li}_{3} \mathrm{Bi} .
\end{aligned}
$$

The above reaction and the complete mechanism with plateau voltages during charging and discharging have been explained by many researchers [60-62] and can be understood by the schematic diagram as shown in Figure $4 \mathrm{~b}$. The first discharge reaction (lithiation) occurs around 1.5-1.7 V depending on element $X$, where $\mathrm{Bi}_{2} \mathrm{X}_{3}$ converts into $\mathrm{Li}_{2} \mathrm{X}$ and $\mathrm{Bi}$ through a conversion reaction. On further discharging, the second reaction takes place at $0.77 \mathrm{~V}$, in which the formation of LiBi takes place, and in the last reaction during discharging, at $0.7 \mathrm{~V}$, the formation of $\mathrm{Li}_{3} \mathrm{Bi}$ occurs. During the charging, a reverse process takes place by the transformation of $\mathrm{Li}_{3} \mathrm{Bi}$ into $\mathrm{Bi}$ at $0.8 \mathrm{~V}$ in the first step whereas the second step is completed by the conversion of $\mathrm{Li}_{2} \mathrm{X}$ into $\mathrm{X}$ at $1.7-2.0 \mathrm{~V}$. 
(a)

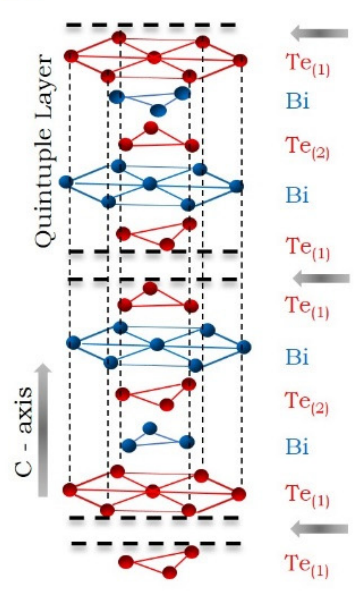

(b)

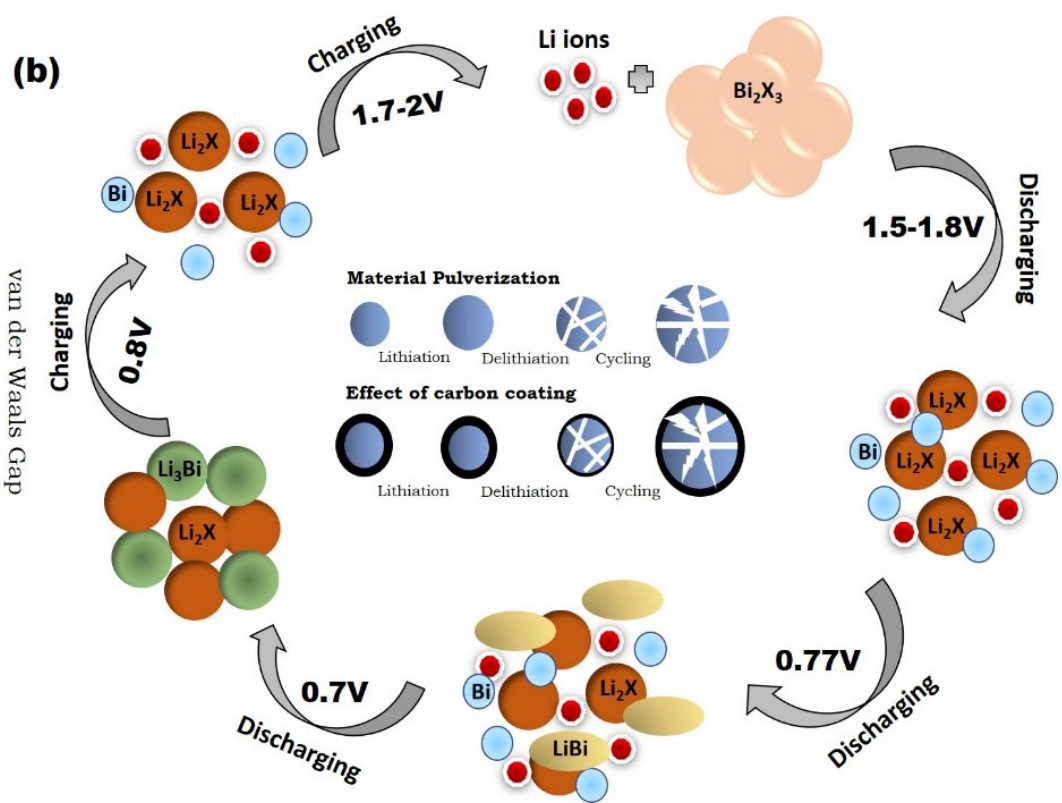

Figure 4. (a) Schematic diagram of the crystal structure of $\mathrm{Bi}_{2} \mathrm{X}_{3} ;(\mathbf{b})$ Schematic diagram of the reaction mechanism of the reaction of $\mathrm{Bi}_{2} \mathrm{X}_{3}$ with lithium.

\section{Bismuth Chalcogenides Materials as an Efficient Anode for Li-Ion Batteries}

As mentioned above, all the bismuth chalcogenide materials can accommodate $12 \mathrm{Li}$ ions per mole, which results in the high theoretical capacity of these $\mathrm{Bi}_{2} \mathrm{X}_{3}(\mathrm{X}=\mathrm{S}$, Se, and Te), i.e., $\sim 625, \sim 491$, and $\sim 401 \mathrm{mAhg}^{-1}$, respectively. These values of theoretical capacities are quite higher than the commercial graphite-based anodes. Along with the higher theoretical capacity, their unique layered structure, in which the separate quintuple layers are attached with weak Vander Waal forces, provides a suitable gap between layers to easily accommodate the $\mathrm{Li}$ ions. This makes these materials suitable for Li-ion storage. In the year 1989, Julien proposed the $\mathrm{Li}$ insertion mechanism of $\mathrm{Li}$ in the $\mathrm{Bi}_{2} \mathrm{X}_{3}$ matrix [44]. This mechanism was observed and confirmed by electrochemical potential spectroscopy and linear sweep voltammetry techniques. They reported that the lattice of the chalcogenides allows a limited number of $\mathrm{Li}$ ions into the matrix, and further lithiation results in the reduction of materials into $\mathrm{Li}_{2} \mathrm{X}$. A combination of reactions (1) and (2) ensured a huge volumetric expansion, i.e., $230 \%$ in the case of $\mathrm{Bi}_{2} \mathrm{~S}_{3}$, which is higher than the individual $\mathrm{Bi}$. This volume expansion causes pulverization and cracks even more, and a decay in cyclic stability appeared in the electrochemical performance. Enhancing the cyclic stability of these chalcogenide materials has been considered as a challenge. Among all three $\mathrm{Bi}_{2} \mathrm{X}_{3}(\mathrm{X}=\mathrm{Te}$, Se, and $\mathrm{S}), \mathrm{Bi}_{2} \mathrm{~S}_{3}$ possesses a higher theoretical capacity. However, volume expansion remains an issue.

To investigate the electrochemical performance of $\mathrm{Bi}_{2} \mathrm{~S}_{3}$, many different approaches have been adopted [60-64]. The most common approach is nanostructuring. Zhang and coworkers synthesized dandelion-like microstructures using the facile reflux synthetic route [65]. This work compared the overall electrochemical performance of nanostructured $\mathrm{Bi}_{2} \mathrm{~S}_{3}$ and $\mathrm{Bi}_{2} \mathrm{~S}_{3}$-carbon nanotube (CNT) nanocomposites. They observed the first discharge capacity of $\mathrm{Bi}_{2} \mathrm{~S}_{3}$ and $\mathrm{Bi}_{2} \mathrm{~S}_{3} / \mathrm{CNT}$ composites as 826 and $574 \mathrm{mAhg}^{-1}$. In the first cycle, the discharge capacity of the composite was found less. However, their coulombic efficiency $(63.9 \%)$ was found more than that of $\mathrm{Bi}_{2} \mathrm{~S}_{3}$ nanostructures $(57.8 \%)$. The cyclic capacity of $\mathrm{Bi}_{2} \mathrm{~S}_{3} / \mathrm{CNT}$ composite was found to be better than the $\mathrm{Bi}_{2} \mathrm{~S}_{3}$, i.e., 247.9 and $74.7 \mathrm{mAhg}^{-1}$ after 50 cycles at $100 \mathrm{mAg}^{-1}$ rates. This improved cyclic capacity was attributed to the improved conductivity and buffering effect provided by the CNT, which compensated the volume expansion associated with the formation of $\mathrm{Li}_{2} \mathrm{~S}$ and $\mathrm{Li}_{3} \mathrm{Bi}$. Further, in their next step, they investigated the performance of $\mathrm{Bi}_{2} \mathrm{~S}_{3}$ composites with graphene oxide (GO) [64]. The synthesis of properly anchored $\mathrm{Bi}_{2} \mathrm{~S}_{3}$ nanoparticles in graphene oxide sheets was done via the hydrothermal route. The same method was adopted to 
synthesize $\mathrm{Bi}_{2} \mathrm{~S}_{3}$ nanoparticles without the addition of graphene oxide. The transmission electron microscopy (TEM) images of anchored nanoparticles are depicted in Figure 5a,b,d. This helped to better understand the effect of $\mathrm{GO}$ on the overall electrochemical performance of $\mathrm{Bi}_{2} \mathrm{~S}_{3}$. The size of the nanoparticles was estimated to be $80-100 \mathrm{~nm}$. The anchoring in GO provides some advantages like higher conductivity, efficient accommodation of large volume expansion the same as CNTs, and, additionally, a highly conductive network for rapid electron transport in the electrode during the electrochemical reaction. As evidence of these advantages, the first discharge capacity of the composite was found to be $1073 \mathrm{mAhg}^{-1}$. Further, the cyclic capacity was also found to be comparatively stable, with a capacity of $400.5 \mathrm{mAhg}^{-1}$ at $100 \mathrm{mAg}^{-1}$ rates after 50 cycles. This reversible capacity value was higher than the bare $\mathrm{Bi}_{2} \mathrm{~S}_{3}$ nanoparticles and $\mathrm{Bi}_{2} \mathrm{~S}_{3} / \mathrm{CNT}$ nanocomposites. Bare $\mathrm{Bi}_{2} \mathrm{~S}_{3}$ nanoparticles showed a cyclic capacity of $44.7 \mathrm{mAhg}^{-1}$, which is less than the dandelion-like $\mathrm{Bi}_{2} \mathrm{~S}_{3}$ microstructures. The cycling performance of both the samples are shown in Figure 5c. The possible reason for this was suggested as the agglomeration of nanoparticles during cycling. Additionally, after 10 cycles, the coulombic efficiency of $\mathrm{Bi}_{2} \mathrm{~S}_{3} / \mathrm{GO}$ was found to be $95 \%$, which was attributed to the buffering effect of reduced graphene oxide (rGO) that efficiently mitigates the volume expansion during lithiation and delithiation.
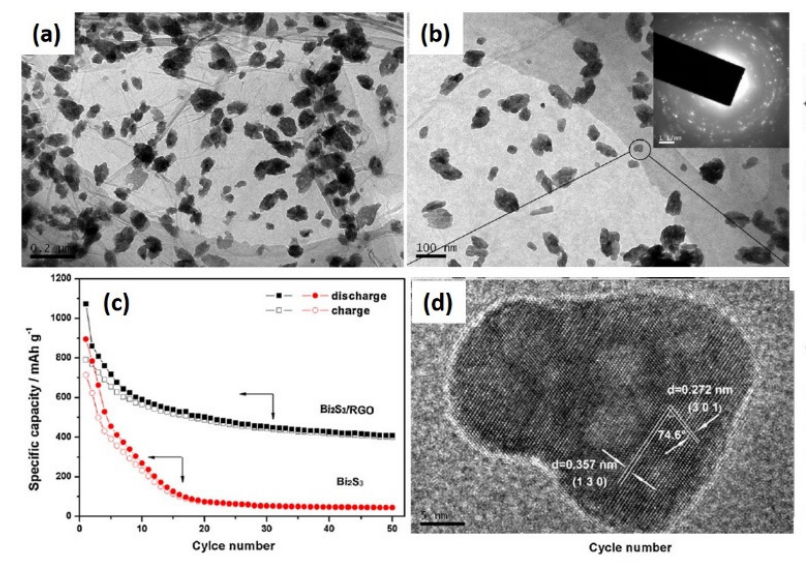

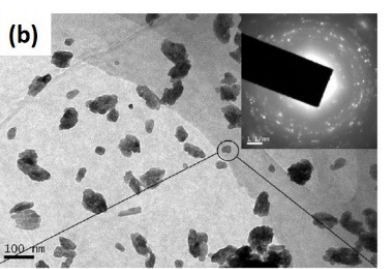

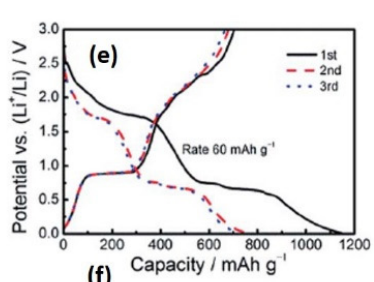

(f) Capacity / $\mathrm{mAh} \mathrm{g}$
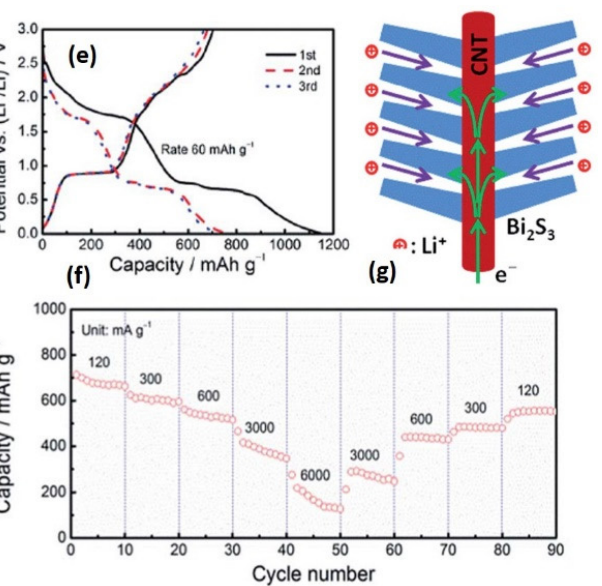

Figure 5. (a,b) Transmission electron microscopy (TEM) images of anchored Bi2S3 nanoparticles in rGO sheets. (c) Cyclic stability of Bi2S3/GO composite and their comparison with bare Bi2S3. (d) High-resolution TEM image of Bi2S3 nanoparticle. Reproduced with permission [64], copyright Elsevier 2013. (e) Galvanostatic charging-discharging. (f) Cycling performance with different current rates of Bi2S3/CNT hybrid structure. (g) Schematic representation of branched Bi2S3 and CNT hybrid structures [668]. Reproduced with permission, copyright 2014, Royal Society of Chemistry.

From the above results, it is confirmed that with the anchoring in carbonaceous materials, the electrochemical performance of $\mathrm{Bi}_{2} \mathrm{~S}_{3}$ can be improved. In a similar direction with a different approach, Zhao and coworkers did interesting work [66]. They prepared the branched structure of $\mathrm{Bi}_{2} \mathrm{~S}_{3}$ with CNT through the sonochemical hydrolysis method. The typical diameter of CNTs was 20-30 nm, and the branched $\mathrm{Bi}_{2} \mathrm{~S}_{3}$ nanorods had a 5-10 nm width and 30-80 nm diameter. The schematic representation of branched structures is given in Figure $5 \mathrm{~g}$. This hierarchical $\mathrm{Bi}_{2} \mathrm{~S}_{3}-\mathrm{CNT}$ hybrid exhibited a high surface area, flexibility, rich porosity, and direct electron transport pathways. These features provided fast electron and ion transport and structural stability during the cycling process. The initial capacities of the hybrid structure were found to be 1146 and $705 \mathrm{mAhg}^{-1}$, provided the coulombic efficiency of $61.5 \%$. The galvanostatic charging-discharging capacity is shown in Figure 5f. The possible reason for obtaining this efficiency was attributed to the deactivation of the conversion production and formation of the SEI layer. This unique structure provided the short diffusion path for the Li ion to move via $\mathrm{Bi}_{2} \mathrm{~S}_{3}$ nanorods. The CNT backbones served the flexible and express path for the rapid charge, which lowered the electrode reaction resistance. As it is previously also mentioned that CNT 
can accommodate the volume expansion during charging and discharging, here, CNT also provided the higher mechanical strength and also efficiently reduced the mechanical stress and strain during the charging and discharging process. The cyclic capacity of the composite with different current rates is shown in Figure 5f.

Similarly, Jung and co-workers [60] synthesized $\mathrm{Bi}_{2} \mathrm{~S}_{3}$ and carbon nanocomposite and further, they compared these materials with bare $\mathrm{Bi}_{2} \mathrm{~S}_{3}$. In comparison to the cyclic capacities of both the samples, the capacity of $\mathrm{Bi}_{2} \mathrm{~S}_{3}$ faded very rapidly while the $\mathrm{Bi}_{2} \mathrm{~S}_{3} / \mathrm{C}$ nanocomposite electrode showed better performance. The primary reason for the excellent performance was the nanosized effects of $\mathrm{Bi}_{2} \mathrm{~S}_{3}$, i.e., large surface area and a reduction in the diffusion length provided better cyclability of the active material. Along with the nanostructuring, an amorphous carbon matrix can accommodate the large volume changes from the active material, while also providing the continuous electric contact network. Further, it acts as a buffer along with the remaining $\mathrm{Li}_{2} \mathrm{~S}$ unreacted during the charging step to accommodate the strain generated due to the large volume changes associated with the formation of $\mathrm{Li}_{3} \mathrm{Bi}$. The $\mathrm{Bi}_{2} \mathrm{~S}_{3} / \mathrm{C}$ anode showed a better performance ca. $500 \mathrm{mAhg}^{-1}$ and $85 \%$ capacity retention over the 100 cycles. These results were very promising towards the application of $\mathrm{Bi}_{2} \mathrm{~S}_{3}$ as an anode of Li-ion batteries. There are also several other reports on different combinations of carbon-based materials and approaches towards the improvement in the battery performance [67-72].

Similar to $\mathrm{Bi}_{2} \mathrm{~S}_{3}$, different approaches towards enhancing the electrochemical performance of $\mathrm{Bi}_{2} \mathrm{Se}_{3}$ were taken into account. To accommodate the volume expansion along with the carbonaceous matrix, metal ion doping was proposed as an attractive way. By taking this approach, Han and co-workers synthesized indium-doped $\mathrm{Bi}_{2} \mathrm{Se}_{3}$ nanostructures through the cation exchange approach [73]. Usually, cation exchange is considered as a versatile approach in nanostructure synthesis. In this approach, the nanostructures' transformation with appreciable control in the composition, morphology, crystal structure, and doping level can be achieved. In cation exchange, the ionic component of chemical bonds in inorganic materials permits the exchange of one element with the other in the ionic form. They synthesized similar $\mathrm{Bi}_{2} \mathrm{Se}_{3}$ nanostructures to compare the effect of doping on the electrochemical performance. SEM images of In-doped and undoped nanostructures are shown in Figure 6a,b. The first discharge capacity of the doped nanostructures was $997.9 \mathrm{mAhg}^{-1}$ while the undoped $\mathrm{Bi}_{2} \mathrm{Se}_{3}$ showed $723.4 \mathrm{mAhg}^{-1}$. The possible reason for this additional capacity was suggested as a result of the lower charge resistance of In-doped $\mathrm{Bi}_{2} \mathrm{Se}_{3}$, as measured through electrochemical impedance spectroscopy (EIS). The cyclic capacity of doped nanostructures was found to be better than the undoped one as shown in Figure 6c. Doped and undoped $\mathrm{Bi}_{2} \mathrm{Se}_{3}$ nanostructures sustained a reversible capacity of 160.3 and $42.3 \mathrm{mAhg}^{-1}$ after 50 cycles at the $50 \mathrm{mAg}^{-1}$ rate, respectively. Even at different current rates, the cyclic performance was found to be better as depicted in Figure $6 \mathrm{~d}$. The better electrochemical performance was achieved due to negligible diffusion through ultrathin nanosheets and faster phase transition. Another possible reason could be the higher surface area, which provided the large contact interface between doped nanostructures and electrolytes. In doping plays a significant role here due to the enhanced carrier density. The cyclic performance of these In-doped $\mathrm{Bi}_{2} \mathrm{Se}_{3}$ nanostructures was higher than $\mathrm{Bi}_{2} \mathrm{Se}_{3}$ nanosheets [74,75], microrods [76], etc.

The $\mathrm{Bi}_{2} \mathrm{Se}_{3}$ with $\mathrm{C}$ and $\mathrm{CNT}$ composites have been shown to have an improved electrochemical performance compared to the metal ion doping [77]. In this work, $\mathrm{Bi}_{2} \mathrm{Se}_{3}$ nanosheets and their composites with $\mathrm{C}$ and CNT were synthesized using the solvothermal technique. SEM images of the synthesized nanocomposites are shown in Figure 6e,f. These composites showed a specific capacity of $432 \mathrm{mAhg}^{-1}$ after 100 cycles at the current density of $100 \mathrm{mAg}^{-1}$. The more interesting point was that even at a high current density, i.e., $2000 \mathrm{mAg}^{-1}$, the specific capacity was maintained at $224 \mathrm{mAhg}^{-1}$. At a higher rate, i.e., $1000 \mathrm{mAg}^{-1}$, composites sustain $242 \mathrm{mAhg}^{-1}$ up to 300 cycles as shown in Figure 6g. In this work, basically, two approaches were combined, i.e., nanostructuring and carbon addition. The advantage of these approaches could be seen in the electrochemical performance. The enhancement in the electrochemical performance was due to the numerous nanocrystals presented in the nanosheets, which caused the shortening of the diffusion path and accommodation of the volume 
change during electrochemical cycling. Further, the higher surface area of the electrode led to the large contact interfaces between the active material and anode. The additional effect could be seen due to the addition of CNTs. CNTs are flexible conductive networks that accelerate the charge transfer, resulting in the reduction in electrode reaction resistance. It is a known fact that carbon materials consist of high mechanical strength that can also accommodate the stress and strain generation during cycling. These factors are responsible for the excellent electrochemical performance of $\mathrm{Bi}_{2} \mathrm{Se}_{3} / \mathrm{C} / \mathrm{CNT}$ composites.
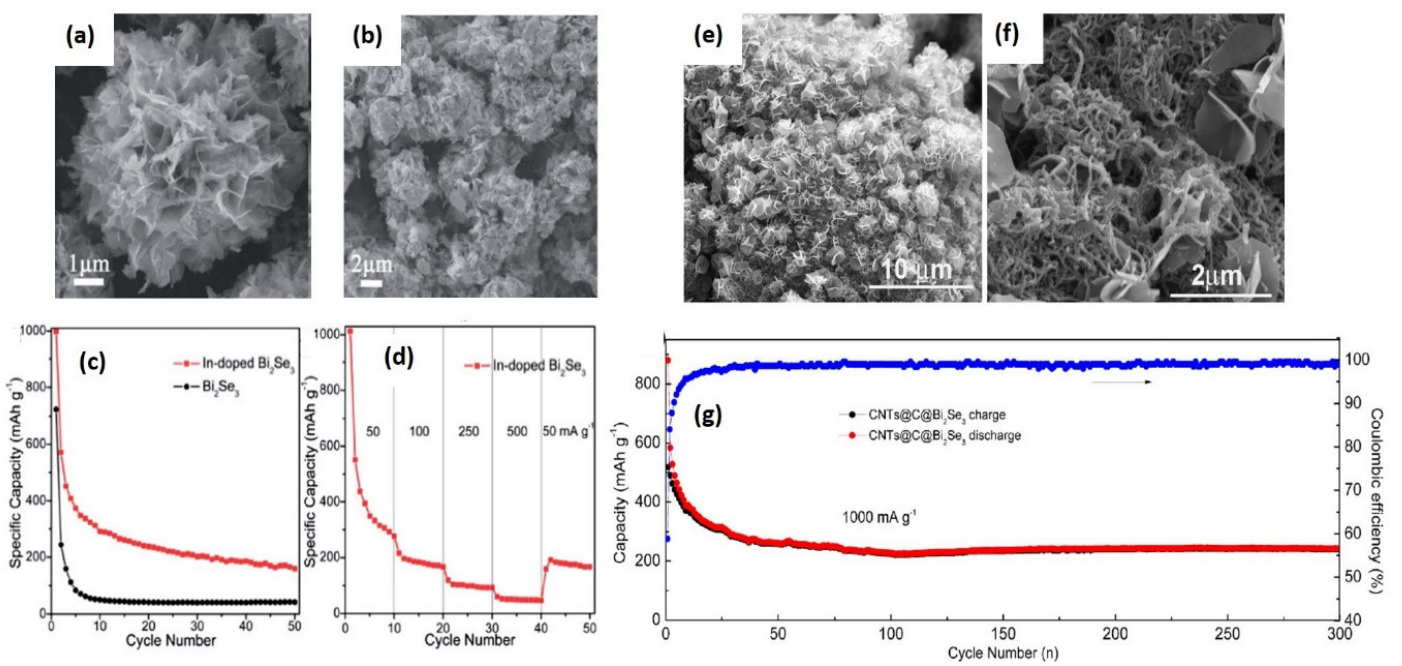

Figure 6. (a) Scanning electron microscopy (SEM) image of In-doped $\mathrm{Bi}_{2} \mathrm{Se}_{3}$ nanostructures, (b) SEM image of undoped $\mathrm{Bi}_{2} \mathrm{Se}_{3}$ nanostructures, (c) cycling performance of doped and undoped $\mathrm{Bi}_{2} \mathrm{Se}_{3}$; (d) cycling performance at different current rates, images are reproduced with permission [73], Copyright (2014), Royal Society of Chemistry. (e) and (f) SEM images of CNTs/C/Bi $\mathrm{Se}_{3}$ nanocomposites; (g) cycling performance of $\mathrm{CNTs} / \mathrm{C} / \mathrm{Bi}_{2} \mathrm{Se}_{3}$ composites. Reproduced with permission [77], Copyright (2017), Elsevier.

To enhance the cyclic stability of $\mathrm{Bi}_{2} \mathrm{Te}_{3}$, Masood et al. prepared $\mathrm{Bi}_{2} \mathrm{Te}_{3}$ and graphene oxide (GO) composites [31]. The adopted method for synthesis was the polyol method, which signified the distribution of $\mathrm{Bi}_{2} \mathrm{Te}_{3}$ into the $\mathrm{GO}$ matrix. The prepared composite showed the first discharge and charge capacity as 752 and $514 \mathrm{mAhg}^{-1}$, respectively, at the current density of $0.1 \mathrm{Ag}^{-1}$. These values were higher than the theoretical capacity of $\mathrm{Bi}_{2} \mathrm{Te}_{3}$ itself, due to the formation of the SEI layer. By incorporating $\mathrm{Bi}_{2} \mathrm{Te}_{3}$ into the GO matrix, the electrical conductivity due to fast Li-ion diffusion was observed to be enhanced. Further, this matrix helped to accommodate the volume changes. The excellent cyclability was found to be $110 \mathrm{mAhg}^{-1}$ in the 500th cycle at the current rate of $0.1 \mathrm{Ag}^{-1}$. These were promising results, which indicated that the GO matrix may help to enhance the cyclability. However, the higher value of the specific capacity was still lacking. Tu et al. prepared $\mathrm{Bi}_{2} \mathrm{Te}_{3}$ nanoplates and graphene nanocomposites to provide a higher electrical conductivity to graphite to enhance the electrochemical performance [78]. Graphene is a monolayer of $\mathrm{sp}^{2}$-bonded carbon atoms that possess higher electronic conductivity, excellent mechanical properties, and a higher specific area [79-82]. These properties make graphene a preferable conducting medium for Li-ion batteries. $\mathrm{Bi}_{2} \mathrm{Te}_{3}$ nanoplates were prepared by the solvothermal method and then composites with $\mathrm{Bi}_{2} \mathrm{Te}_{3}$ nanoplates were prepared for the investigation of electrochemical performance. The SEM of $\mathrm{Bi}_{2} \mathrm{Te}_{3}$ nanoplate/graphene is shown in Figure 7a. The understanding of cyclic voltammetry $(\mathrm{CV})$ is imperative to discuss first. As depicted in Figure $7 b$, the $\mathrm{CV}$ of $\mathrm{Bi}_{2} \mathrm{Te}_{3} /$ graphene nanocomposites at $50 \mathrm{mAg}^{-1}$ up to 4 cycles suggested a multi-step reaction of $\mathrm{Li}$ with $\mathrm{Bi}_{2} \mathrm{Te}_{3}$. In the first cathodic scan, three different reduction peaks were observed at 2, 1.25 , and $0.6 \mathrm{~V}$. These peaks were attributed to lithium insertion, and the formation of $\mathrm{Li}_{2} \mathrm{Te}$ and formation of $\mathrm{Li}_{3} \mathrm{Bi}$, respectively. The reaction mechanism could be understood by the schematic diagram shown in Figure 4. In the second scan, peaks were observed at 1.65, 1.35, and 
0.7 V. The peaks at 1.65 and $1.35 \mathrm{~V}$ indicated that the reaction of Te and Li occurred via a two-step reaction with the formation of $\mathrm{LiTe}_{3}$ and $\mathrm{Li}_{2} \mathrm{Te}$. These phases have been reported as stable phases at room temperature [83]. The first discharge capacity of the composite was found to be higher, which was attributed to the formation of a solid electrolyte interface (SEI) layer. The specific capacity of the bare $\mathrm{Bi}_{2} \mathrm{Te}_{3}$ rapidly decayed whereas $\mathrm{Bi}_{2} \mathrm{Te}_{3} /$ graphene nanocomposites showed a relatively better performance as shown in Figure 7c. The reason for the stability was proposed based on the restricted crystal growth of $\mathrm{Bi}_{2} \mathrm{Te}_{3}$ due to graphene, resulting in easy diffusion in the $\mathrm{Bi}_{2} \mathrm{Te}_{3}$ matrix. Additionally, separated layers of graphene sheets provided extra vacancies for the Li ion due to the contact sites between the electrolyte. The cyclic performance of the $\mathrm{Bi}_{2} \mathrm{Te}_{3} /$ graphene composites was also found to be better than bare $\mathrm{Bi}_{2} \mathrm{Te}_{3}$ as depicted in Figure $7 \mathrm{~d}$. After 50 cycles, the charge capacity was obtained as 158 and $33 \mathrm{mAhg}^{-1}$ in case of $\mathrm{Bi}_{2} \mathrm{Te}_{3} /$ graphene and bare $\mathrm{Bi}_{2} \mathrm{Te}_{3}$, respectively. The enhanced cyclic capacity was due to the buffering effect of conducting graphene that restrains the aggregation of $\mathrm{Bi}_{2} \mathrm{Te}_{3}$ plates and restricts the volume expansion. Further, this structure also offered the Li-ion diffusion within the free space through the electrode and electrolyte interface. This work was quite important in the direction of the application of $\mathrm{Bi}_{2} \mathrm{Te}_{3}$ and their composites for Li-ion batteries.
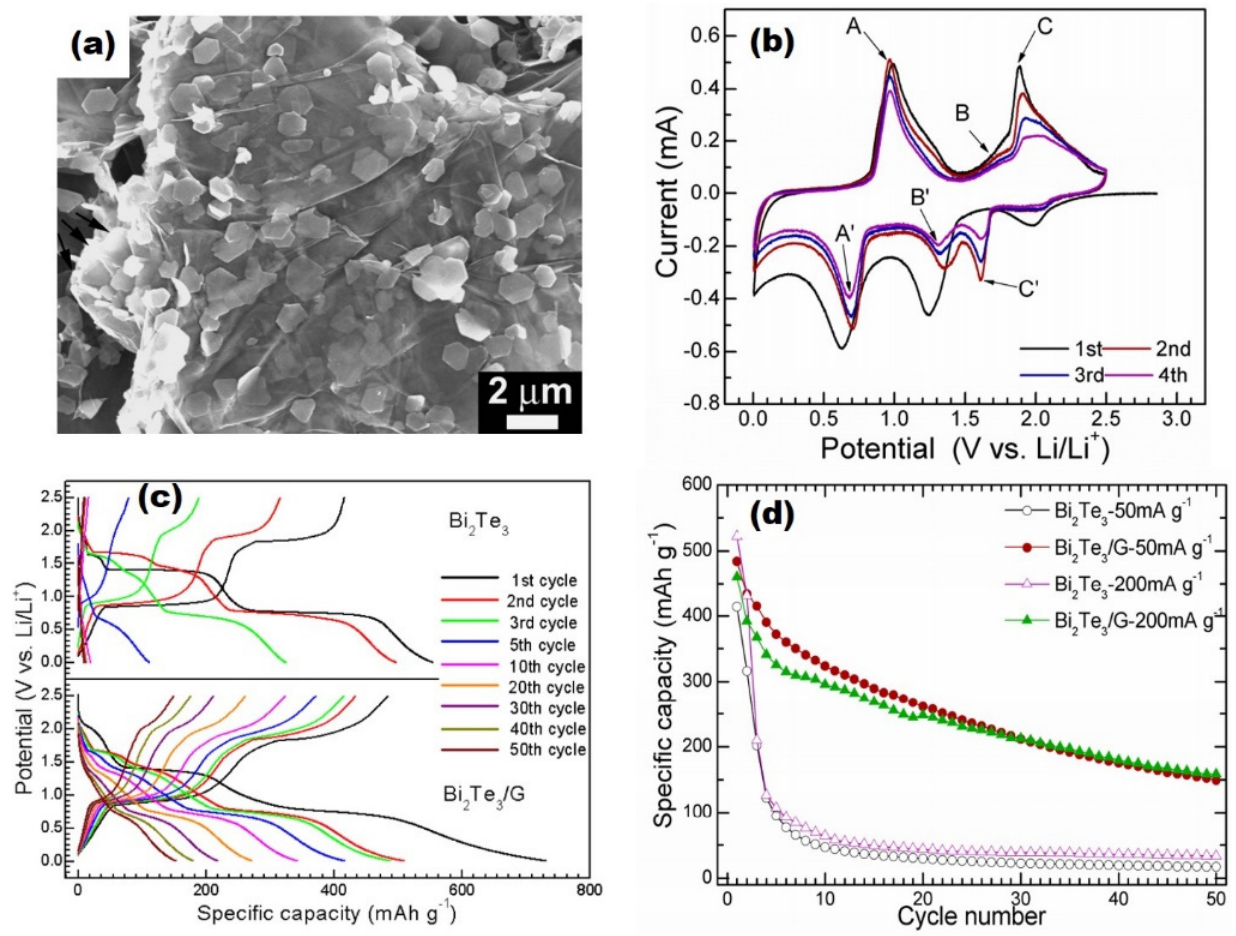

Figure 7. (a) $\mathrm{SEM}$ image of $\mathrm{Bi}_{2} \mathrm{Te}_{3}$ nanoplates and graphene nanocomposites, (b) Cyclic voltammetry at $100 \mathrm{mAg}^{-1}$. (c) Galvanostatic charge-discharge performance of bare $\mathrm{Bi}_{2} \mathrm{Te}_{3}$ and $\mathrm{Bi}_{2} \mathrm{Te}_{3} / \mathrm{G}$, (d) Cycling performance of $\mathrm{Bi}_{2} \mathrm{Te}_{3}$ and $\mathrm{Bi}_{2} \mathrm{Te}_{3} /$ graphene composites at two different current rates [78]. Reproduced with permission, copyright 2012, MDPI.

\section{Bismuth Chalcogenides as the Anode in All-Solid-State Lithium-Ion Batteries}

It is already mentioned above that all-solid-state batteries attracted great attention as a next-generation Li-ion battery. Along with the non-flammable behavior of solid electrolytes, they can utilize Li-metal anodes and are able to effectively suppress the formation and growth of Li dendrites. Therefore, the solid-electrolyte strategy provides great opportunities to enhance the safety and energy density of lithium-based batteries [18,84-88]. $\mathrm{LiBH}_{4}$ has been considered as a promising solid-state electrolyte in recent years. It consists of an orthorhombic phase at room temperature, which changes to the hexagonal phase at high temperatures $\left(115^{\circ} \mathrm{C}\right)$ [89]. This high-temperature phase shows higher conductivity $\left(10^{-3} \mathrm{Scm}^{-1}\right.$ at $\left.115^{\circ} \mathrm{C}\right)$ than the other sulfide-based electrolytes as well as polymer-based 
electrolytes. The establishment of this electrolyte for all-solid-state Li-ion batteries has already been reported by several researchers [90-93]. All the experiments are conducted at a constant current rate, i.e., $0.1 \mathrm{C}$. The $\mathrm{C}$ rate is a measure of the charge and discharge current with respect to its capacity. The $1 \mathrm{C}$ rate delivers the battery's total capacity in $1 \mathrm{~h}$. A schematic diagram of the all-solid-state Li-ion battery is shown in Figure 8.

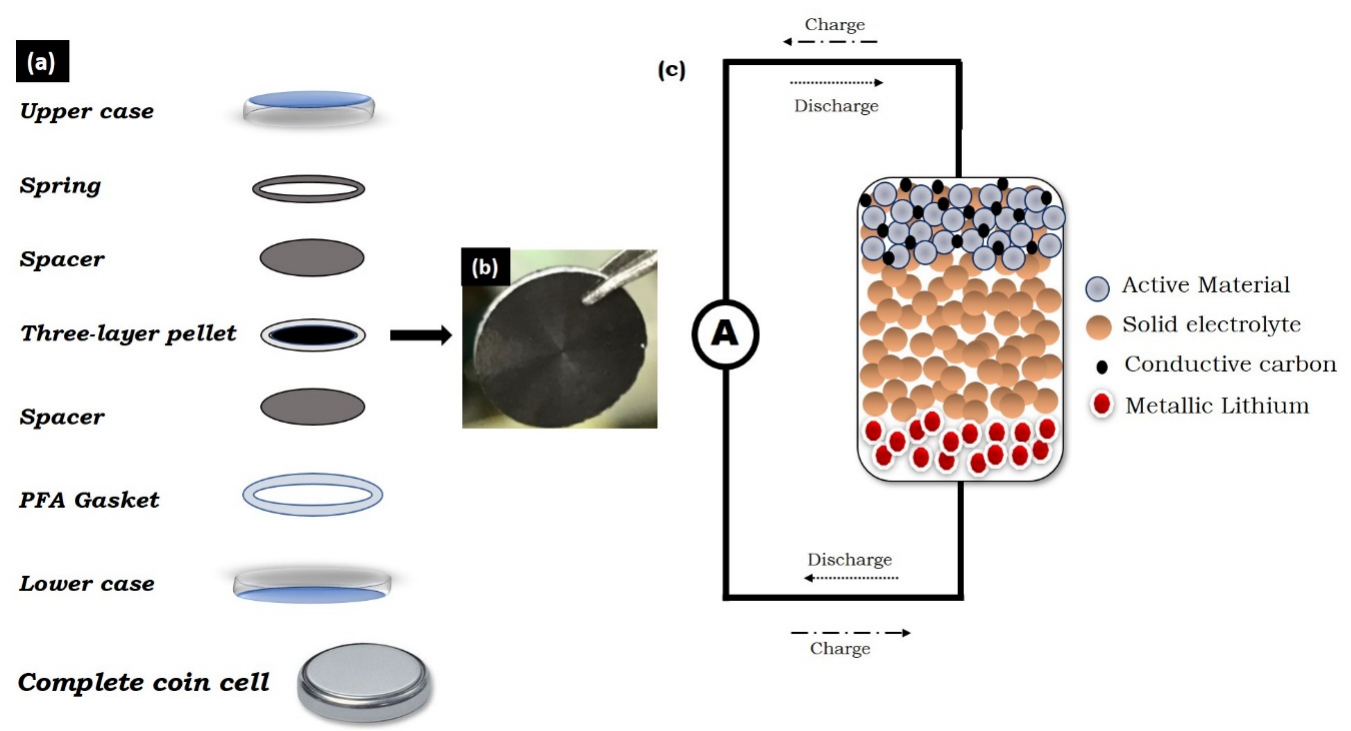

Figure 8. (a) Schematic diagram of the cell assembly; (b) picture of the actual prepared pellet and (c) schematic illustration of the working of the all-solid-state lithium ion battery.

In 2018, nanostructured $\mathrm{Bi}_{2} \mathrm{Te}_{3}$ anodes were utilized in Li-ion batteries with lithium borohydride $\left(\mathrm{LiBH}_{4}\right)$ as a solid electrolyte [94]. These nanostructures contained quite a high amount of oxide; thus, the obtained capacity was higher than the theoretical capacity of $\mathrm{Bi}_{2} \mathrm{Te}_{3}$. However, it suffered from poor stability due to the reduction of $\mathrm{LiBH}_{4}$ through the reaction with $\mathrm{Bi}_{2} \mathrm{O}_{3}$. Later, to avoid the contribution of oxide in the anode performance, bulk $\mathrm{Bi}_{2} \mathrm{Te}_{3}, \mathrm{Bi}_{2} \mathrm{Se}_{3}$, and $\mathrm{Bi}_{2} \mathrm{~S}_{3}$ were investigated as anode materials $[61,62,95,96]$. In these works, $\mathrm{LiBH}_{4}$ was used as a solid-state electrolyte. The sample preparation of the anode materials for Li-ion batteries included the $2-\mathrm{h}$ milling of $\mathrm{Bi}_{2} \mathrm{X}_{3}$, acetylene black (AB), and $\mathrm{LiBH}_{4}$. The reason for including $\mathrm{AB}$ and $\mathrm{LiBH}_{4}$ was to enhance the conductivity of the material and to provide the path to $\mathrm{Li}$ ions to move with ease. Further, $\mathrm{Li}$ foil as a counter electrode, $\mathrm{LiBH}_{4}$ as a solid-state electrolyte, and the prepared mixture of the anode was taken to form a three-layered pellet, which was sealed into coin cells for all the electrochemical measurements. The confirmation of separate phases corresponding to $\mathrm{LiBH}_{4}$ and $\mathrm{Bi}_{2} \mathrm{X}_{3}$ was done using an X-ray diffraction pattern. This implied that no reaction occurred between $\mathrm{Bi}_{2} \mathrm{X}_{3}$ and $\mathrm{LiBH}_{4}$ during milling except the case for $\mathrm{Bi}_{2} \mathrm{~S}_{3}$. In the case of the $\mathrm{Bi}_{2} \mathrm{~S}_{3} / \mathrm{LiBH}_{4} / \mathrm{AB}$ composite, a mechanochemical reaction occurred during milling as well as heating at $120^{\circ} \mathrm{C}$, which converted the initial composite to $\mathrm{Li}_{2} \mathrm{~S}$ and Bi phases [61].

Initially, all the electrochemical tests were performed between 0.2 and $2.5 \mathrm{~V}$. The galvanostatic charge-discharge profile is depicted in Figure 6a. Generally, in $\mathrm{Bi}_{2} \mathrm{X}_{3}$ samples, the plateau at around 1.5-1.7 $\mathrm{V}$ occurred, corresponding to the movement of $\mathrm{Li}$ ions towards the anode from the cathode and the conversion reaction with $\mathrm{Bi}_{2} \mathrm{X}_{3}(X=S$, Se, and $\mathrm{Te})$, which resulted in the formation of $\mathrm{Li}_{2} \mathrm{X}(\mathrm{X}=\mathrm{Se}$ and $\mathrm{Te}$ ) and $\mathrm{Bi}$. As mentioned above, due to the initial reaction of sulfur at the higher temperature, i.e., $120^{\circ} \mathrm{C}, \mathrm{Bi}_{2} \mathrm{~S}_{3}$ was completely transformed into $\mathrm{Bi}$ and $\mathrm{Li}_{2} \mathrm{~S}$, which caused the elimination of the above plateau in the discharge profile of the $\mathrm{Bi}_{2} \mathrm{~S}_{3}$ composite. The second and third plateaus in the discharge reaction were observed at 0.75 and $0.71 \mathrm{~V}$, which corresponded to the alloying reaction of $\mathrm{Bi}$ and $\mathrm{Li}$ and formation of $\mathrm{LiBi}$ and $\mathrm{Li}_{3} \mathrm{Bi}$, respectively [58]. During charging, these plateaus again appeared at 
$0.82 \mathrm{~V}$, which shows the reversibility of the reaction. The reaction mechanism was established through the CV and XRD results and compiled though the equation mentioned below [94-98]:

$$
\mathrm{Bi}_{2} \mathrm{X}_{3}+6 \mathrm{Li} \leftrightarrow 2 \mathrm{Li}_{2} \mathrm{X}+2 \mathrm{Bi}+\mathrm{Li} \leftrightarrow 3 \mathrm{Li}_{2} \mathrm{X}+\mathrm{Bi}+\mathrm{LiBi}+5 \mathrm{Li} \leftrightarrow 3 \mathrm{Li}_{2} \mathrm{X}+2 \mathrm{Li}_{3} \mathrm{Bi}
$$

In $\mathrm{Bi}_{2} \mathrm{~S}_{3}$, the first discharge and charge capacities were found to be 617 and $1145 \mathrm{mAhg}^{-1}$, respectively, as shown in Figure 9a. The discharge capacity was quite similar to the theoretical capacity of $\mathrm{Bi}_{2} \mathrm{~S}_{3}$, i.e., $625 \mathrm{mAhg}^{-1}$. The higher value of the charge capacity was proposed due to the thermochemical side reaction between the freshly formed $S$ (as a result of de-lithiation of $\mathrm{Li}_{2} \mathrm{~S}$ ) and $\mathrm{LiBH}_{4}$. This thermochemical reaction caused a poor cyclability and the cell stopped working after only a few cycles. To avoid these thermochemical reactions, the voltage window was restricted from 0.2-1.5 V. The limited potential window helped to achieve a higher cyclic stability and successful operation of the coin cell. After 50 cycles, the discharge capacity was observed to be $311 \mathrm{mAhg}^{-1}$ as shown in Figure $9 b$, which is quite higher than the $\mathrm{Bi}_{2} \mathrm{~S}_{3}$ nanostructures used with liquid electrolytes earlier [57,65]. Similarly, in the $\mathrm{Bi}_{2} \mathrm{Se}_{3}$ sample, the prepared anode showed the first discharge capacity of $621 \mathrm{mAhg}^{-1}$ whereas the charge capacity was found to be $1346 \mathrm{mAhg}^{-1}$. These values were quite higher than the actual theoretical capacity $\left(491 \mathrm{mAhg}^{-1}\right)$ of $\mathrm{Bi}_{2} \mathrm{Se}_{3}$ anodes. The galvanostatic charge-discharge of $\mathrm{Bi}_{2} \mathrm{Se}_{3}$ is also depicted in Figure 9a. In the discharge capacity, the additional capacity was suggested due to the carbon contribution or other side reaction. The higher charging capacity was believed to be due to the same reason as mentioned above for the $\mathrm{Bi}_{2} \mathrm{~S}_{3}$ composite. The occurrence of this thermochemical reaction was also confirmed by the noise in the cyclic voltammetry results [61]. This thermochemical reaction hurdled the cycling and the cell stopped working after 10-15 cycles due to the loss of connectivity. The loss of connectivity was confirmed from the SEM micrographs, where the cracks were visible due to these reactions. To eliminate these reactions, the cell potential window was restricted up to $1.5 \mathrm{~V}$, similar to $\mathrm{Bi}_{2} \mathrm{~S}_{3}$ composites. The first discharge capacity was found to be $621 \mathrm{mAhg}^{-1}$, which decreased to $306 \mathrm{mAhg}^{-1}$ after the 50th cycle as shown in Figure 9b. Even after restricting the potential window, the cyclic capacity was still quite high in comparison to the $\mathrm{Bi}_{2} \mathrm{Se}_{3}$ nanostructure and their composites reported previously [71,73,74]. After the 50th cycle, no cracks or crumbling were observed in the SEM micrograph. This represented that the restriction of the potential window was advantageous for the elimination of the side reaction and enhancement of the cyclability. A similar behavior was observed for the $\mathrm{Bi}_{2} \mathrm{Te}_{3}$ composite also, where the first discharge and charge capacity was found to be 515 and $1349 \mathrm{mAhg}^{-1}$. After the 50th cycle, the specific discharge capacity was found to be $235 \mathrm{mAhg}^{-1}$ as depicted in Figure $9 \mathrm{~b}$ [93]. The cyclic capacity of bulk $\mathrm{Bi}_{2} \mathrm{X}_{3}$ after 50 cycles was found to be higher than the reported values for liquid electrolytes $[57,65,68,69,72,74,76,94]$. A comparison of the values in tabular form is given in Table 1.
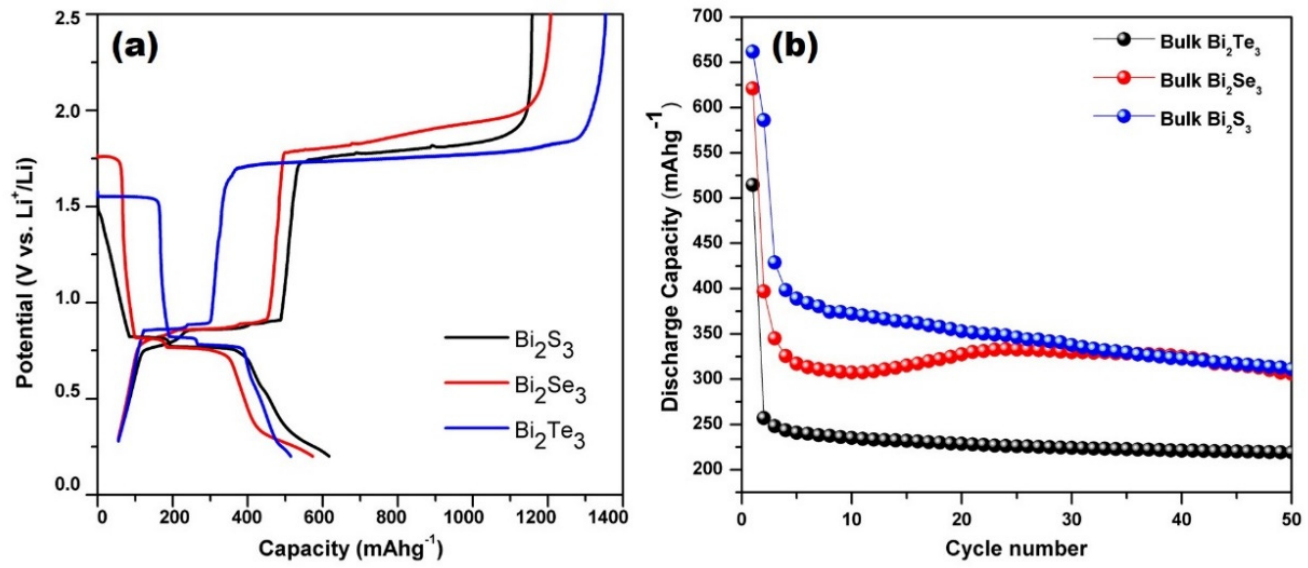

Figure 9. (a) First galvanostatic charge-discharge capacity of bulk $\mathrm{Bi}_{2} \mathrm{X}_{3}$ in the voltage range $0.2-2.5 \mathrm{~V}$ at the $0.1 \mathrm{C}$ rate; (b) Cyclic capacity of $\mathrm{Bi}_{2} \mathrm{X}_{3}$ up to 50 cycles. 
Table 1. Comparitive of discharge and cyclic capacities of different bismuth chalcogenide bulk and nanostructures.

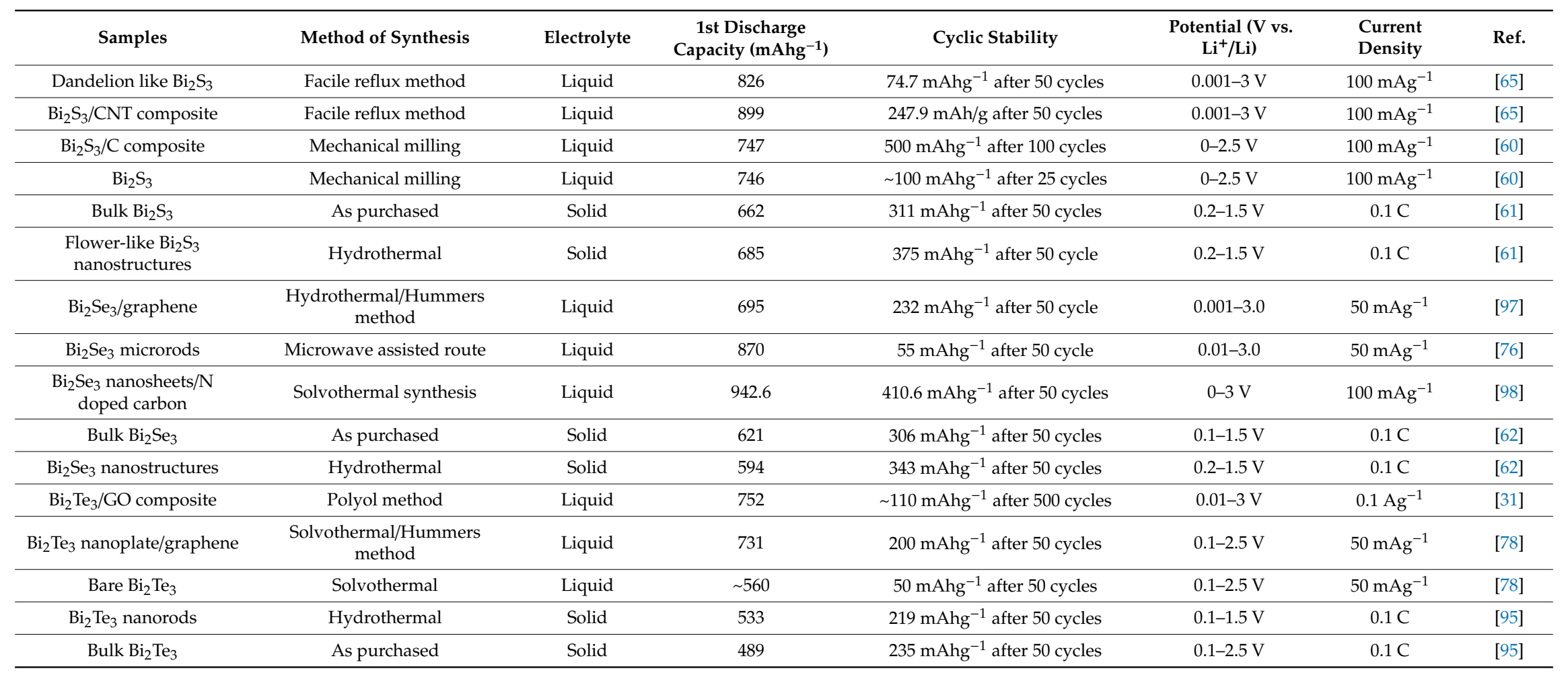


The main problem with these $\mathrm{Bi}_{2} \mathrm{X}_{3}$ materials is volume expansion during the electrochemical reaction, which causes a loss in electrical connections during charging and discharging. This problem could be eliminated in all-solid-state batteries. The homogenous distribution of active material throughout the cell, and the addition of $\mathrm{AB}$ and $\mathrm{LiBH}_{4}$ works as the binder and provides a cushioning effect, thus accommodating the volume expansion easily, which results in an improved cyclic performance.

Previously $[61,62,95,96]$, it was proposed that the long charging plateau around $1.7 \mathrm{~V}$ was due to the conversion reaction of $\mathrm{Li}_{2} \mathrm{X}$ to $\mathrm{X}$ and the simultaneous thermochemical reaction between freshly formed $\mathrm{X}$ and $\mathrm{LiBH}_{4}$ presented in the anode layer. This reaction proceeded until $\mathrm{LiBH}_{4}$ completely reacted with $X$ materials, which provided excess Li ions. However, no experimental evidence was provided to support our earlier work. Recently, electrochemical charging/discharging was performed for each element, i.e., $\mathrm{Bi}, \mathrm{S}, \mathrm{Se}$, and Te, as the electrode material. The composites of each element with $\mathrm{LiBH}_{4}$ and $\mathrm{AB}$ were prepared similarly, and finally, three-layered pellets for each composite were placed in coin cells. The galvanostatic discharge/charge profiles of all four samples are shown in Figure 10. From the figure, it is clear that the reaction plateau of $\mathrm{Bi}$ and Te-based composites are at the same position, i.e., 1.7 V. Whereas, the position of the de-lithiation plateau for $\mathrm{Li}_{2} \mathrm{Se}$ and $\mathrm{Li}_{2} \mathrm{~S}$ to $\mathrm{Se}$ and $S$ is higher, i.e., $1.9 \mathrm{~V}$. So, it is concluded from this additional investigation that the long plateau above $1.5 \mathrm{~V}$ for all the $\mathrm{Bi}_{2} \mathrm{X}_{3}$ composites (except $\mathrm{Bi}_{2} \mathrm{Te}_{3}$ ) was mainly the result of the thermochemical reaction between readily available $\mathrm{Bi}$ (de-lithiation potential from $\mathrm{Li}_{3} \mathrm{Bi}$ to $\mathrm{Bi}$ is $0.7-0.8 \mathrm{~V}$ ) and $\mathrm{LiBH}_{4}$, thus forming $\mathrm{Li}_{3} \mathrm{Bi}$, which immediately de-lithiated into Bi again due to the electrochemical reaction at this potential. This cyclic process continued until the complete consumption of $\mathrm{LiBH}_{4}$, which provided an excess amount of $\mathrm{Li}$ ions. In the case of $\mathrm{Bi}_{2} \mathrm{Te}_{3}, \mathrm{Te}$ also contributed to the thermochemical reaction between $\mathrm{Te}$ and $\mathrm{LiBH}_{4}$. The availability of Te could be possible from the de-lithiation of $\mathrm{Li}_{2} \mathrm{Te}$ at this potential in contrast to the higher potential of delithiation for $\mathrm{Li}_{2} \mathrm{~S}$ and $\mathrm{Li}_{2} \mathrm{Se}$.

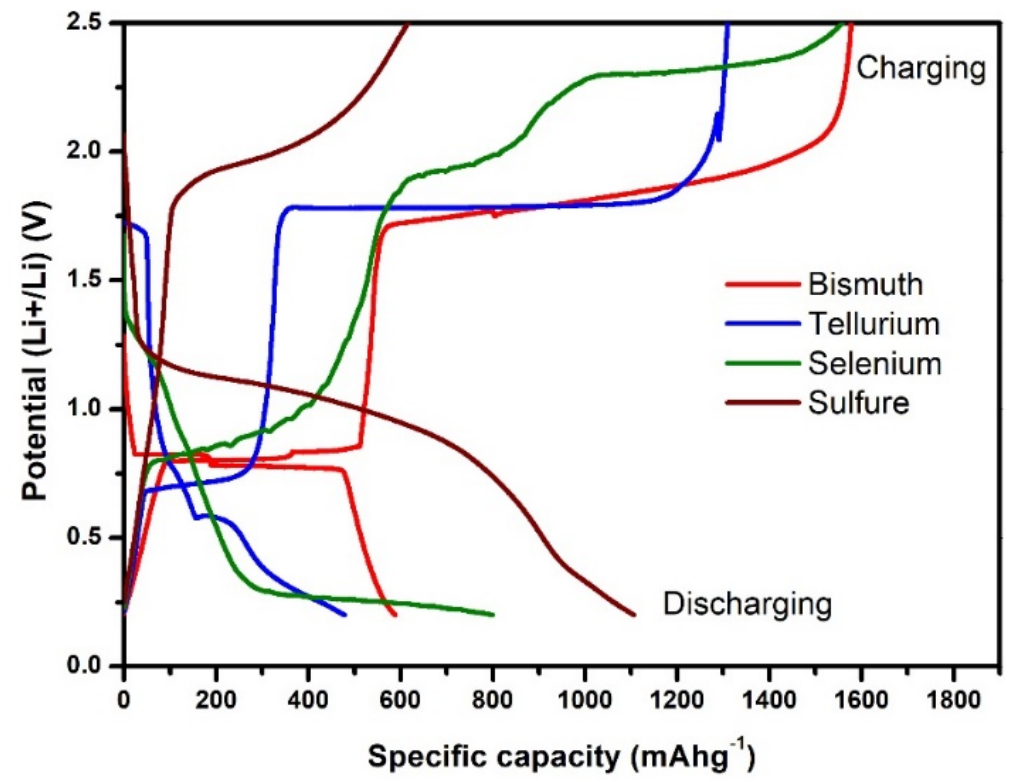

Figure 10. Galvanostatic charging-discharging curve for the first cycle of $\mathrm{Bi}, \mathrm{S}, \mathrm{Se}$, and Te in the potential window of $0.1-2.5 \mathrm{~V}$.

To further explore the effect of nanostructuring on the overall electrochemical performance of these materials, $\mathrm{Bi}_{2} \mathrm{X}_{3}$ nanostructures were prepared and electrochemically tested for the all-solid-state Li-ion battery [61]. $\mathrm{Bi}_{2} \mathrm{X}_{3}$ nanostructures were prepared by the hydrothermal synthesis route. Flower-like $\mathrm{Bi}_{2} \mathrm{~S}_{3}$ nanostructures were proven to be efficient anodes for all-solid-state Li-ion batteries. The assembly of nanorods having an average diameter of $70 \mathrm{~nm}$ and an average length of $300 \mathrm{~nm}$ in a flower-like 
morphology was observed. The main advantage of nanostructuring is the shortening of the Li diffusion path. In the voltage range of $0.2-1.5 \mathrm{~V}$, the first galvanostatic discharge-charge capacities for these $\mathrm{Bi}_{2} \mathrm{~S}_{3}$ nanoflower composites were found to be 685 and $494 \mathrm{mAhg}^{-1}$ at the $0.1 \mathrm{C}$ rate. The coulombic efficiency was found to be $95.8 \%$, which is higher than the liquid electrolyte. In comparison with bulk $\mathrm{Bi}_{2} \mathrm{~S}_{3}$, the initial discharge capacity of the nanostructures was lower. However, the cyclic stability was found to be better in nano $\mathrm{Bi}_{2} \mathrm{~S}_{3}$ composite anodes. After the 50th cycle, the cyclic capacity was observed as $352 \mathrm{mAhg}^{-1}$, which was higher than bulk $\mathrm{Bi}_{2} \mathrm{~S}_{3}$. The total decay in capacity was found to be $29.5 \%$ in comparison to $47 \%$ for bulk $\mathrm{Bi}_{2} \mathrm{~S}_{3}$ composites. This nanoflower-like morphology has a higher surface area and excellent charge transfer kinetics due to the reduced diffusion path. These results showed that the electrochemical performance of $\mathrm{Bi}_{2} \mathrm{~S}_{3}$ in all-solid-state Li-ion batteries can be improved through nanostructuring. Some similar effects were also observed in $\mathrm{Bi}_{2} \mathrm{Se}_{3}$ and $\mathrm{Bi}_{2} \mathrm{Te}_{3}$ nanostructure composite anode materials. $\mathrm{Bi}_{2} \mathrm{Se}_{3}$ nanostructures in a mixed morphology, i.e., nanoparticles and nanosheets, were prepared by the hydrothermal method [59]. These prepared nanostructures showed a first discharge capacity as $594 \mathrm{mAhg}^{-1}$, which was faded down to $343 \mathrm{mAhg}^{-1}$ in the 50th cycle. The coulombic efficiency till the 50th cycle was maintained at $99 \%$, which is higher than the reported anodes [71,74]. The cyclic stability was found to be better in comparison to bulk $\mathrm{Bi}_{2} \mathrm{Se}_{3}$. After the 50th cycle, the specific capacity for bulk $\mathrm{Bi}_{2} \mathrm{Se}_{3}$ was $306 \mathrm{mAhg}^{-1}$ in comparison to $343 \mathrm{mAhg}^{-1}$ for nanostructured $\mathrm{Bi}_{2} \mathrm{Se}_{3}$. $\mathrm{Bi}_{2} \mathrm{Te}_{3}$ nanorods showed similar effects on the electrochemical performance of composite electrodes [95]. The first discharge capacity of $\mathrm{Bi}_{2} \mathrm{Te}_{3}$ nanorods was observed to be 489 $\mathrm{mAhg}^{-1}$, which remained at $235 \mathrm{mAhg}^{-1}$ after the 50th cycle, which is slightly higher than the bulk $\mathrm{Bi}_{2} \mathrm{Te}_{3}\left(219 \mathrm{mAhg}^{-1}\right)$.

\section{Summary and Future Outlook}

In this review paper, we discussed the recent progress of bismuth chalcogenide materials for conventional Li-ion batteries using liquid electrolyte as well as all-solid-state Li-ion batteries. The reaction mechanism of lithium storage in these materials has been well established. These materials have been proven as the superior anodes for lithium-ion batteries with a simple two-step conversion and alloying reaction during lithiation/de-lithiation. The high capacity of 400-625 mAhg ${ }^{-1}$ in comparison to conventional carbon materials attracted researchers worldwide to employ these for practical purposes; however, there are some hurdles to use it as an anode material practically. Large volume expansion is the main issue with bismuth chalcogenide materials. During the past few decades, researchers have put huge efforts into solving these issues through various methods. The first method chosen to overcome these hurdles was nanostructuring. Various nanostructures with different dimensionality were developed and explored for the higher electrochemical performances as compared to the bulk $\mathrm{Bi}_{2} \mathrm{X}_{3}$ materials. Among the several advantages of these nanostructures, the availability of a higher number of active sites and excellent mechanical strength are the main factors that significantly contribute to enhancing the overall performance of $\mathrm{Bi}_{2} \mathrm{X}_{3}$-based anode materials. Carbon-based materials were also used to synthesize the composites to enhance the conductivity and to accommodate the volume expansion during the cycling of these materials.

The excellent approach to switch from the liquid electrolytes to solid-state batteries is a promising way to enhance the performance of overall batteries. A comparison of the electrochemical performance of $\mathrm{Bi}_{2} \mathrm{X}_{3}$ materials in all-solid-state batteries with the conventional Li-ion batteries using liquid electrolytes was made herein. From the obtained results, it was concluded that solid-state batteries are a good alternative for conventional batteries and can be adopted for next-generation Li-ion batteries. The discussed solid-state batteries were mainly composed of $\mathrm{LiBH}_{4}$ as a solid-state electrolyte and $\mathrm{Bi}_{2} \mathrm{X}_{3} / \mathrm{LiBH}_{4} / \mathrm{AB}$ composites as the electrode. Even though side thermochemical reactions were observed during the operation of these solid-state batteries, the capacity and stability was found to be better for these in comparison to the conventional batteries using liquid electrolytes, e.g., the all-solid-state battery using a $\mathrm{Bi}_{2} \mathrm{~S}_{3}$ (bulk)/ $/ \mathrm{LBH}_{4} / \mathrm{AB}$ composite anode showed a capacity of $311 \mathrm{mAh} / \mathrm{g}$ in comparison to $<250 \mathrm{mAh} / \mathrm{g}$ for the $\mathrm{Bi}_{2} \mathrm{~S}_{3} / \mathrm{CNT}$ composite in a conventional battery after 50 cycles. 
Although, $\mathrm{LiBH}_{4}$ has a higher conductivity and could be employed for these electrode materials with high stability; however, it has the limitations of a higher working temperature as well as a side thermochemical reaction at a higher potential. These issues lowered the overall capacity in comparison to the theoretical capacity. In the future, it would be interesting to modify $\mathrm{LiBH}_{4}$ for its room temperature operation or to explore other solid electrolytes (e.g., sulfide-based electrolytes) with high conductivity at room temperature. The use of sulfide-based electrolytes not only provides a low working temperature, but it may also help to avoid side thermochemical reactions that occur in the case of $\mathrm{LiBH}_{4}$.

Funding: This work was partially supported by DST, New Delhi (IFA-13/PH-84), SERB, New Delhi (ECR/2016/1780, ECR/2016/1888) and UGC-DAE CSR, Indore (CSR-IC-MSRSR-23/CRS-231/2017-18/1312, CSR-IC/CRS-73/2014-15/581).

Conflicts of Interest: The authors declare no conflict of interest.

\section{References}

1. Dunn, B.; Kamath, H.; Tarascon, J.-M. Electrical energy storage for the grid: A battery of choices. Science 2011, 334, 928-935. [CrossRef]

2. Nitta, N.; Wu, F.; Lee, J.T.; Yushin, G. Li-ion battery materials: Present and future. Mater. Today 2015, 18, 252-264. [CrossRef]

3. Zhang, W.-J. A review of the electrochemical performance of alloy anodes for lithium-ion batteries. J. Power Sources 2011, 196, 13-24. [CrossRef]

4. Abruña, H.D.; Kiya, Y.; Henderson, J.C. Batteries and electrochemical capacitors. Phys. Today 2008, 61, 43-47. [CrossRef]

5. Staffell, I.; Scamman, D.; Abad, A.V.; Balcombe, P.; Dodds, P.E.; Ekins, P.; Shah, N.; Ward, K.R. The role of hydrogen and fuel cells in the global energy system. Energy Environ. Sci. 2019, 12, 463-491.

6. Vielstich, W.; Lamm, A.; Gasteiger, H.A. Handbook of Fuel Cells: Fundamentals Technology and Applications; Wiley: New York, NY, USA, 2003; Volume 2.

7. Linden, D. Handbook of Batteries and Fuel Cells; McGraw-Hill Education: New York, NY, USA, 1984.

8. Hovel, H.J. Solar cells. STIA 1975, 76, 20650.

9. Grätzel, M. Dye-sensitized solar cells. J. Photochem. Photobiol. C Photochem. Rev. 2003, 4, 145-153. [CrossRef]

10. Wang, L.; Zhang, G.; Liu, Q.; Duan, H. Recent progress in Zn-based anodes for advanced lithium ion batteries. Mater. Chem. Front. 2018, 2, 1414-1435. [CrossRef]

11. Xu, J.-J.; Zhang, X.-B. Li-air batteries: Decouple to stabilize. Nat. Energy 2017, 2, 1-2. [CrossRef]

12. Zhou, G.; Li, F.; Cheng, H.-M. Progress in flexible lithium batteries and future prospects. Energy Environ. Sci. 2014, 7, 1307-1338. [CrossRef]

13. Vetter, J.; Novák, P.; Wagner, M.R.; Veit, C.; Möller, K.-C.; Besenhard, J.O.; Winter, M.; Wohlfahrt-Mehrens, M.; Vogler, C.; Hammouche, A. Ageing mechanisms in lithium-ion batteries. J. Power Sources 2005, 147, 269-281. [CrossRef]

14. Balakrishnan, P.G.; Ramesh, R.; Kumar, T.P. Safety mechanisms in lithium-ion batteries. J. Power Sources 2006, 155, 401-414. [CrossRef]

15. Lu, L.; Han, X.; Li, J.; Hua, J.; Ouyang, M. A review on the key issues for lithium-ion battery management in electric vehicles. J. Power Sources 2013, 226, 272-288. [CrossRef]

16. Van Schalkwijk, W.; Scrosati, B. Advances in lithium ion batteries introduction. In Advances in Lithium-Ion Batteries; Springer: London, UK, 2002; pp. 1-5.

17. Cao, K.; Jin, T.; Yang, L.; Jiao, L. Recent progress in conversion reaction metal oxide anodes for Li-ion batteries. Mater. Chem. Front. 2017, 1, 2213-2242. [CrossRef]

18. Zheng, F.; Kotobuki, M.; Song, S.; Lai, M.O.; Lu, L. Review on solid electrolytes for all-solid-state lithium-ion batteries. J. Power Sources 2018, 389, 198-213. [CrossRef]

19. Oudenhoven, J.F.M.; Baggetto, L.; Notten, P.H.L. All-solid-state lithium-ion microbatteries: A review of various three-dimensional concepts. Adv. Energy Mater. 2011, 1, 10-33. [CrossRef]

20. Sun, C.; Liu, J.; Gong, Y.; Wilkinson, D.P.; Zhang, J. Recent advances in all-solid-state rechargeable lithium batteries. Nano Energy 2017, 33, 363-386. [CrossRef] 
21. Sakuda, A.; Hayashi, A.; Tatsumisago, M. Sulfide solid electrolyte with favorable mechanical property for all-solid-state lithium battery. Sci. Rep. 2013, 3, 2261. [CrossRef]

22. Quartarone, E.; Mustarelli, P. Review_emerging trends in the design of electrolytes for lithium and post-lithium batteries. J. Electrochem. Soc. 2020, 167, 50508. [CrossRef]

23. Tuller, H. Ionic conduction and applications BT. In Springer Handbook of Electronic and Photonic Materials; Kasap, S., Capper, P., Eds.; Springer International Publishing: Basel, Switzerland, 2017; p. 1. ISBN 978-3-319-48933-9.

24. Wang, Z.; Shao, G. Theoretical design of solid electrolytes with superb ionic conductivity: Alloying effect on $\mathrm{Li}^{+}$transportation in cubic $\mathrm{Li}_{6} \mathrm{PA}_{5} \mathrm{X}$ chalcogenides. J. Mater. Chem. A 2017, 5, 21846-21857. [CrossRef]

25. Umeshbabu, E.; Zheng, B.; Yang, Y. Recent progress in all-solid-state Lithium-Sulfur batteries using high Li-ion conductive solid electrolytes. Electrochem. Energy Rev. 2019, 1-32. [CrossRef]

26. Uitz, M.; Epp, V.; Bottke, P.; Wilkening, M. Ion dynamics in solid electrolytes for lithium batteries. J. Electroceramics. 2017, 38, 142-156. [CrossRef]

27. Li, Q.; Chen, J.; Fan, L.; Kong, X.; Lu, Y. Progress in electrolytes for rechargeable Li-based batteries and beyond. Green Energy Environ. 2016, 1, 18-42. [CrossRef]

28. Blomgren, G.E. Liquid electrolytes for lithium and lithium-ion batteries. J. Power Sources 2003, 119-121, 326-329.

29. Tirado, J.L. Inorganic materials for the negative electrode of lithium-ion batteries: State-of-the-art and future prospects. Mater. Sci. Eng. R Rep. 2003, 40, 103-136. [CrossRef]

30. Zhang, W.-J. Lithium insertion/extraction mechanism in alloy anodes for lithium-ion batteries. J. Power Sources 2011, 196, 877-885. [CrossRef]

31. Masood, K.B.; Jain, N.; Singh, J. Electrochemical performance of $\mathrm{Bi}_{2} \mathrm{Te}_{3} / \mathrm{GO}$ composite anode for LIB application. Int. J. Appl. Ceram. Technol. 2020, 17, 1422-1429. [CrossRef]

32. Wang, R.Y.; Feser, J.P.; Gu, X.; Yu, K.M.; Segalman, R.A.; Majumdar, A.; Milliron, D.J.; Urban, J.J. Universal and solution-processable precursor to bismuth chalcogenide thermoelectrics. Chem. Mater. 2010, 22, 1943-1945. [CrossRef]

33. Mizuguchi, Y.; Omachi, A.; Goto, Y.; Kamihara, Y.; Matoba, M.; Hiroi, T.; Kajitani, J.; Miura, O. Enhancement of thermoelectric properties by Se substitution in layered bismuth-chalcogenide $\mathrm{LaOBiS}_{2-\mathrm{x}} \mathrm{Se}_{\mathrm{x}}$. J. Appl. Phys. 2014, 116, 163915. [CrossRef]

34. Chung, D.Y.; Hogan, T.; Schindler, J.; Iordarridis, L.; Brazis, P.; Kannewurf, C.R.; Chen, B.; Uher, C.; Kanatzidis, M.G. Complex bismuth chalcogenides as thermoelectrics. In Proceedings of the XVI ICT'97. Proceedings ICT'97. 16th International Conference on Thermoelectrics (Cat. No.97TH8291), Dresden, Germany, 26-29 August 1997; IEEE: Piscataway, NJ, USA, 1997; pp. 459-462.

35. Kim, S.; Lee, Y.-I.; Choi, Y.-M.; Lim, H.-R.; Lim, J.-H.; Myung, N.V.; Choa, Y.-H. Thermochemical hydrogen sensor based on chalcogenide nanowire arrays. Nanotechnology 2015, 26, 145503. [CrossRef]

36. Sharma, A.; Bhattacharyya, B.; Srivastava, A.K.; Senguttuvan, T.D.; Husale, S. High performance broadband photodetector using fabricated nanowires of bismuth selenide. Sci. Rep. 2016, 6, 19138. [CrossRef]

37. Yao, J.D.; Shao, J.M.; Yang, G.W. Ultra-broadband and high-responsive photodetectors based on bismuth film at room temperature. Sci. Rep. 2015, 5, 12320. [CrossRef] [PubMed]

38. Xing, C.; Huang, W.; Xie, Z.; Zhao, J.; Ma, D.; Fan, T.; Liang, W.; Ge, Y.; Dong, B.; Li, J.; et al. Ultrasmall Bismuth quantum dots: Facile liquid-phase exfoliation, characterization, and application in high-performance UV-vis photodetector. ACS Photonics 2018, 5, 621-629. [CrossRef]

39. Savariraj, A.D.; Vinoth, V.; Mangalaraja, R.V.; Arun, T.; Contreras, D.; Akbari-Fakhrabadi, A.; Valdés, H.; Banat, F. Microwave-assisted synthesis of localized surface plasmon resonance enhanced bismuth selenide $\left(\mathrm{Bi}_{2} \mathrm{Se}_{3}\right)$ layers for non-enzymatic glucose sensing. J. Electroanal. Chem. 2020, 856, 113629. [CrossRef]

40. Li, X.; Zhong, L.; Liu, R.; Wei, X.; Li, J. A molecularly imprinted photoelectrochemical sensor based on the use of $\mathrm{Bi}_{2} \mathrm{~S}_{3}$ for sensitive determination of dioctyl phthalate. Microchim. Acta 2019, 186, 688. [CrossRef]

41. Deng, J.; Zhao, Z.-Y. Electronic structure and optical properties of bismuth chalcogenides $B_{2} \mathrm{Q}_{3}(\mathrm{Q}=\mathrm{O}, \mathrm{S}, \mathrm{Se}$, Te) by first-principles calculations. Comput. Mater. Sci. 2018, 142, 312-319. [CrossRef]

42. Mishra, S.K.; Satpathy, S.; Jepsen, O. Electronic structure and thermoelectric properties of bismuth telluride and bismuth selenide. J. Phys. Condens. Matter 1997, 9, 461. [CrossRef]

43. Ding, Z.; Bux, S.K.; King, D.J.; Chang, F.L.; Chen, T.-H.; Huang, S.-C.; Kaner, R.B. Lithium intercalation and exfoliation of layered bismuth selenide and bismuth telluride. J. Mater. Chem. 2009, 19, 2588-2592. [CrossRef] 
44. Julien, C.; Sararas, I.; Chevy, A. Studies of lithium insertion in bismuth chalcogenide compounds. Solid State Ion. 1989, 36, 113-120. [CrossRef]

45. Bludská, J.; Jakubec, I.; Karamazov, S.; Horák, J.; Uher, C. Lithium ions in the van der Waals gap of $\mathrm{Bi}_{2} \mathrm{Se}_{3}$ single crystals. J. Solid State Chem. 2010, 183, 2813-2817. [CrossRef]

46. Bludská, J.; Jakubec, I.; Lošt'ák, P.; Horák, J. Lithium intercalation into the tetradymite-type selenides $\mathrm{Bi}_{2-\mathrm{x}} \mathrm{In}_{\mathrm{x}} \mathrm{Se}_{3}$. Philos. Mag. B 1997, 76, 867-873. [CrossRef]

47. Sarakonsri, T.; Johnson, C.S.; Hackney, S.A.; Thackeray, M.M. Solution route synthesis of $\mathrm{InSb}_{\mathrm{S}} \mathrm{Cu}_{6} \mathrm{Sn}_{5}$ and $\mathrm{Cu}_{2} \mathrm{Sb}$ electrodes for lithium batteries. J. Power Sources 2006, 153, 319-327. [CrossRef]

48. Xie, J.; Zhao, X.B.; Cao, G.S.; Zhong, Y.D.; Zhao, M.J.; Tu, J.P. Solvothermal synthesis of nanosized CoSb 2 alloy anode for Li-ion batteries. Electrochim. Acta 2005, 50, 1903-1907. [CrossRef]

49. Chen, W.X.; Lee, J.Y.; Liu, Z. The nanocomposites of carbon nanotube with $\mathrm{Sb}$ and $\mathrm{SnSb}_{0.5}$ as Li-ion battery anodes. Carbon 2003, 41, 959-966.

50. Hassoun, J.; Derrien, G.; Panero, S.; Scrosati, B. The role of the morphology in the response of Sb-C nanocomposite electrodes in lithium cells. J. Power Sources 2008, 183, 339-343. [CrossRef]

51. Applestone, D.; Yoon, S.; Manthiram, A. $\mathrm{Mo}_{3} \mathrm{Sb}_{7}-\mathrm{C}$ composite anodes for lithium-ion batteries. J. Phys. Chem. C 2011, 115, 18909-18915. [CrossRef]

52. Xianming, W.; Nishina, T.; Uchida, I. Lithium alloy formation at bismuth thin layer and its kinetics in propylene carbonate electrolyte. J. Power Sources 2002, 104, 90-96. [CrossRef]

53. Park, C.-M.; Yoon, S.; Lee, S.-I.; Sohn, H.-J. Enhanced electrochemical properties of nanostructured bismuth-based composites for rechargeable lithium batteries. J. Power Sources 2009, 186, 206-210. [CrossRef]

54. Yang, F.; Yu, F.; Zhang, Z.; Zhang, K.; Lai, Y.; Li, J. Bismuth nanoparticles embedded in carbon spheres as anode materials for sodium/lithium-ion batteries. Chem. Eur. J. 2016, 22, 2333-2338. [CrossRef]

55. Dai, R.; Wang, Y.; Da, P.; Wu, H.; Xu, M.; Zheng, G. Indirect growth of mesoporous Bi@C core-shell nanowires for enhanced lithium-ion storage. Nanoscale 2014, 6, 13236-13241. [CrossRef]

56. Crosnier, O.; Brousse, T.; Devaux, X.; Fragnaud, P.; Schleich, D.M. New anode systems for lithium ion cells. J. Power Sources 2001, 94, 169-174. [CrossRef]

57. Zhao, Y.; Manthiram, A. High-capacity, high-rate Bi-Sb alloy anodes for lithium-ion and sodium-ion batteries. Chem. Mater. 2015, 27, 3096-3101. [CrossRef]

58. Zhong, Y.; Li, B.; Li, S.; Xu, S.; Pan, Z.; Huang, Q.; Xing, L.; Wang, C.; Li, W. Bi nanoparticles anchored in $\mathrm{N}$-doped porous carbon as anode of high energy density lithium ion battery. Nano-Micro Lett. 2018, 10, 56.

59. Kumari, P.; Sharma, K.; Pal, P.; Kumar, M.; Ichikawa, T.; Jain, A. Highly efficient \& stable Bi \& Sb anodes using lithium borohydride as solid electrolyte in Li-ion batteries. RSC Adv. 2019, 9, 13077-13081.

60. Jung, H.; Park, C.-M.; Sohn, H.-J. Bismuth sulfide and its carbon nanocomposite for rechargeable lithium-ion batteries. Electrochim. Acta 2011, 56, 2135-2139. [CrossRef]

61. Kumari, P.; Awasthi, K.; Agarwal, S.; Ichikawa, T.; Kumar, M.; Jain, A. Flower-like $\mathrm{Bi}_{2} \mathrm{~S}_{3}$ nanostructures as highly efficient anodes for all-solid-state lithium-ion batteries. RSC Adv. 2019, 9, 29549-29555. [CrossRef]

62. Kumari, P.; Singh, R.; Awasthi, K.; Ichikawa, T.; Kumar, M.; Jain, A. Highly stable nanostructured Bi $\mathrm{Be}_{3}$ anode material for all solid-state lithium-ion batteries. J. Alloys Compd. 2020, 838, 155403. [CrossRef]

63. Zhao, Y.; Gao, D.; Ni, J.; Gao, L.; Yang, J.; Li, Y. One-pot facile fabrication of carbon-coated $\mathrm{Bi}_{2} \mathrm{~S}_{3}$ nanomeshes with efficient Li-storage capability. Nano Res. 2014, 7, 765-773. [CrossRef]

64. Zhang, Z.; Zhou, C.; Huang, L.; Wang, X.; Qu, Y.; Lai, Y.; Li, J. Synthesis of bismuth sulfide/reduced graphene oxide composites and their electrochemical properties for lithium ion batteries. Electrochim. Acta 2013, 114, 88-94. [CrossRef]

65. Zhang, Z.; Zhou, C.; Lu, H.; Jia, M.; Lai, Y.; Li, J. Facile synthesis of dandelion-like $\mathrm{Bi}_{2} \mathrm{~S}_{3}$ microspheres and their electrochemical properties for lithium-ion batteries. Mater. Lett. 2013, 91, 100-102. [CrossRef]

66. Zhao, Y.; Liu, T.; Xia, H.; Zhang, L.; Jiang, J.; Shen, M.; Ni, J.; Gao, L. Branch-structured $\mathrm{Bi}_{2} \mathrm{~S}_{3}-\mathrm{CNT}$ hybrids with improved lithium storage capability. J. Mater. Chem. A 2014, 2, 13854-13858. [CrossRef]

67. Ni, J.; Zhao, Y.; Liu, T.; Zheng, H.; Gao, L.; Yan, C.; Li, L. Strongly coupled $\mathrm{Bi}_{2} \mathrm{~S}_{3} @$ CNT hybrids for robust lithium storage. Adv. Energy Mater. 2014, 4, 1400798. [CrossRef]

68. Tang, C.; Li, N.; Sheng, J.; Zhou, L.; He, L.; Zhu, J.; Li, F.; Liu, Y.; Mai, L. Facile synthesis of $\mathrm{Bi}_{2} \mathrm{~S}_{3} @ \mathrm{SiO}_{2}$ core-shell microwires as high-performance anode materials for lithium-ion batteries. J. Electrochem. Soc. 2016, 164, A6110. [CrossRef] 
69. Hu, P.; Cao, Y.; Lu, B. Flowerlike assemblies of $\mathrm{Bi}_{2} \mathrm{~S}_{3}$ nanorods by solvothermal route and their electrochemical hydrogen storage performance. Mater. Lett. 2013, 106, 297-300. [CrossRef]

70. Ma, J.; Liu, Z.; Lian, J.; Duan, X.; Kim, T.; Peng, P.; Liu, X.; Chen, Q.; Yao, G.; Zheng, W. Ionic liquids-assisted synthesis and electrochemical properties of Bi2S3 nanostructures. CrystEngComm 2011, 13, 3072-3079. [CrossRef]

71. Zhou, H.; Xiong, S.; Wei, L.; Xi, B.; Zhu, Y.; Qian, Y. Acetylacetone-directed controllable synthesis of $\mathrm{Bi}_{2} \mathrm{~S}_{3}$ nanostructures with tunable morphology. Cryst. Growth Des. 2009, 9, 3862-3867. [CrossRef]

72. Ma, J.; Yang, J.; Jiao, L.; Wang, T.; Lian, J.; Duan, X.; Zheng, W. $\mathrm{Bi}_{2} \mathrm{~S}_{3}$ nanomaterials: Morphology manipulation and related properties. Dalt. Trans. 2011, 40, 10100-10108. [CrossRef] [PubMed]

73. Han, G.; Chen, Z.-G.; Ye, D.; Yang, L.; Wang, L.; Drennan, J.; Zou, J. In-doped Bi ${ }_{2} \mathrm{Se}_{3}$ hierarchical nanostructures as anode materials for Li-ion batteries. J. Mater. Chem. A 2014, 2, 7109-7116. [CrossRef]

74. Ali, Z.; Cao, C.; Li, J.; Wang, Y.; Cao, T.; Tanveer, M.; Tahir, M.; Idrees, F.; Butt, F.K. Effect of synthesis technique on electrochemical performance of bismuth selenide. J. Power Sources 2013, 229, 216-222. [CrossRef]

75. Jin, R.; Liu, J.; Xu, Y.; Li, G.; Chen, G.; Yang, L. Hierarchical $\mathrm{Bi}_{2} \mathrm{Se}_{3-\mathrm{x}} \mathrm{S}_{\mathrm{x}}$ microarchitectures assembled from ultrathin polycrystalline nanosheets: Solvothermal synthesis and good electrochemical performance. J. Mater. Chem. A 2013, 1, 10942-10950. [CrossRef]

76. Xu, H.; Chen, G.; Jin, R.; Pei, J.; Wang, Y.; Chen, D. Hierarchical $\mathrm{Bi}_{2} \mathrm{Se}_{3}$ microrods: Microwave-assisted synthesis, growth mechanism and their related properties. CrystEngComm 2013, 15, 1618-1625. [CrossRef]

77. Jin, R.; Sun, M.; Li, G. CNTs@C@ $\mathrm{Bi}_{2} \mathrm{Se}_{3}$ composite as an improved-performance anode for lithium ion batteries. Ceram. Int. 2017, 43, 17093-17099. [CrossRef]

78. Tu, F.; Xie, J.; Cao, G.; Zhao, X. Self-assembly of $\mathrm{Bi}_{2} \mathrm{Te}_{3}$-nanoplate/graphene-nanosheet hybrid by one-pot route and its improved Li-storage properties. Materials 2012, 5, 1275-1284. [CrossRef]

79. Novoselov, K.S.; Geim, A.K.; Morozov, S.V.; Jiang, D.; Zhang, Y.; Dubonos, S.V.; Grigorieva, I.V.; Firsov, A.A. Electric field effect in atomically thin carbon films. Science 2004, 306, 666-669. [CrossRef] [PubMed]

80. Park, S.; An, J.; Jung, I.; Piner, R.D.; An, S.J.; Li, X.; Velamakanni, A.; Ruoff, R.S. Colloidal suspensions of highly reduced graphene oxide in a wide variety of organic solvents. Nano Lett. 2009, 9, 1593-1597. [CrossRef] [PubMed]

81. Stoller, M.D.; Park, S.; Zhu, Y.; An, J.; Ruoff, R.S. Graphene-based ultracapacitors. Nano Lett. 2008, 8, 3498-3502. [CrossRef] [PubMed]

82. Lee, C.; Wei, X.; Kysar, J.W.; Hone, J. Measurement of the elastic properties and intrinsic strength of monolayer graphene. Science 2008, 321, 385-388. [CrossRef] [PubMed]

83. Cunningham, P.T.; Johnson, S.A.; Cairns, E.J. Phase Equilibria in Lithium-Chalcogen Systems: II. Lithium-Sulfur. J. Electrochem. Soc. 1972, 119, 1448.

84. Arya, A.; Sharma, A.L. A glimpse on all-solid-state Li-ion battery (ASSLIB) performance based on novel solid polymer electrolytes: A topical review. J. Mater. Sci. 2020, 1-63. [CrossRef]

85. Yu, X.; Manthiram, A. A long cycle life, all-solid-state lithium battery with a ceramic-polymer composite electrolyte. ACS Appl. Energy Mater. 2020, 3, 2916-2924. [CrossRef]

86. Ding, Z.; Li, J.; Li, J.; An, C. Interfaces: Key issue to be solved for all solid-state lithium battery technologies. J. Electrochem. Soc. 2020, 167, 70541. [CrossRef]

87. Xia, S.; Wu, X.; Zhang, Z.; Cui, Y.; Liu, W. Practical challenges and future perspectives of all-solid-state lithium-metal batteries. Chem 2019, 5, 753-785. [CrossRef]

88. Tan, D.H.S.; Banerjee, A.; Chen, Z.; Meng, Y.S. From nanoscale interface characterization to sustainable energy storage using all-solid-state batteries. Nat. Nanotechnol. 2020, 1-11. [CrossRef]

89. Maekawa, H.; Matsuo, M.; Takamura, H.; Ando, M.; Noda, Y.; Karahashi, T.; Orimo, S. Halide-stabilized $\mathrm{LiBH}_{4}$, a room-temperature lithium fast-ion conductor. J. Am. Chem. Soc. 2009, 131, 894-895. [CrossRef]

90. Zeng, L.; Kawahito, K.; Ikeda, S.; Ichikawa, T.; Miyaoka, H.; Kojima, Y. Metal hydride-based materials towards high performance negative electrodes for all-solid-state lithium-ion batteries. Chem. Commun. 2015, 51, 9773-9776. [CrossRef]

91. Matsuo, M.; Nakamori, Y.; Orimo, S.; Maekawa, H.; Takamura, H. Lithium superionic conduction in lithium borohydride accompanied by structural transition. Appl. Phys. Lett. 2007, 91, 224103. [CrossRef]

92. Unemoto, A.; Yasaku, S.; Nogami, G.; Tazawa, M.; Taniguchi, M.; Matsuo, M.; Ikeshoji, T.; Orimo, S. Development of bulk-type all-solid-state lithium-sulfur battery using $\mathrm{LiBH}_{4}$ electrolyte. Appl. Phys. Lett. 2014, 105, 83901. [CrossRef] 
93. Takahashi, K.; Hattori, K.; Yamazaki, T.; Takada, K.; Matsuo, M.; Orimo, S.; Maekawa, H.; Takamura, H. All-solid-state lithium battery with $\mathrm{LiBH}_{4}$ solid electrolyte. J. Power Sources 2013, 226, 61-64. [CrossRef]

94. Singh, R.; Kumari, P.; Rathore, R.K.; Shinzato, K.; Ichikawa, T.; Verma, A.S.; Saraswat, V.K.; Awasthi, K.; Jain, A.; Kumar, M. $\mathrm{LiBH}_{4}$ as solid electrolyte for $\mathrm{Li}$-ion batteries with $\mathrm{Bi}_{2} \mathrm{Te}_{3}$ nanostructured anode. Int. J. Hydrogen Energy 2018, 43, 21709-21714. [CrossRef]

95. Kumari, P.; Singh, R.; Awasthi, K.; Ichikawa, T.; Jain, A.; Kumar, M. Electrochemical reaction mechanism for $\mathrm{Bi}_{2} \mathrm{Te}_{3}$ based anode material in highly durable all solid state lithium ion batteries. J. Mater. Sci. Mater. Electron. 2020. [CrossRef]

96. Kumari, P.; Pal, P.; Shinzato, K.; Awasthi, K.; Ichikawa, T.; Jain, A.; Kumar, M. Nanostructured $\mathrm{Bi}_{2} \mathrm{Te}_{3}$ as anode material as well as a destabilizing agent for $\mathrm{LiBH}_{4}$. Int. J. Hydrogen Energy 2020, 45, 16992-16999. [CrossRef]

97. Chen, X.; Tang, H.; Huang, Z.; Zhou, J.; Ren, X.; Huang, K.; Qi, X.; Zhong, J. Flexible Bismuth selenide/graphene composite paper for lithium-ion batteries. Ceram. Int. 2017, 43, 1437-1442. [CrossRef]

98. Li, Z.; Pan, H.; Wei, W.; Dong, A.; Zhang, K.; Lv, H.; He, X. Bismuth metal-organic frameworks derived bismuth selenide nanosheets/nitrogen-doped carbon hybrids as anodes for Li-ion batteries with improved cyclic performance. Ceram. Int. 2019, 45, 11861-11867. [CrossRef]

(C) 2020 by the authors. Licensee MDPI, Basel, Switzerland. This article is an open access article distributed under the terms and conditions of the Creative Commons Attribution (CC BY) license (http://creativecommons.org/licenses/by/4.0/). 